University of Florida Levin College of Law

UF Law Scholarship Repository

UF Law Faculty Publications

Faculty Scholarship

2012

\title{
The Rule of Reason and the Goals of Antitrust: An Economic Approach
}

Roger D. Blair

University of Florida, roger.blair@warrington.ufl.edu

D. Daniel Sokol

University of Florida Levin College of Law, sokold@law.ufl.edu

Follow this and additional works at: https://scholarship.law.ufl.edu/facultypub

Part of the Antitrust and Trade Regulation Commons

\section{Recommended Citation}

Roger D. Blair \& D. Daniel Sokol, The Rule of Reason and the Goals of Antitrust: An Economic Approach, 78 Antitrust L.J. 471 (2012), available at http://scholarship.law.ufl.edu/facultypub/292

This Article is brought to you for free and open access by the Faculty Scholarship at UF Law Scholarship Repository. It has been accepted for inclusion in UF Law Faculty Publications by an authorized administrator of UF Law Scholarship Repository. For more information, please contact kaleita@law.ufl.edu. 


\title{
THE RULE OF REASON AND THE GOALS OF ANTITRUST: AN ECONOMIC APPROACH
}

\author{
Roger D. Blair \\ D. DANIEL SOKOL*
}

Since its inception, the Sherman Act's broad language has required judicial interpretation to separate lawful and unlawful conduct under its terms. It is one thing to broadly proscribe collusion and monopolizing behavior, but quite another to apply these broad prohibitions in specific circumstances. Over time, as the Supreme Court interpreted the Sherman Act, certain practices became unlawful per se. A plaintiff_-public or private-had only to prove the fact of the conduct to prevail because the deleterious effects of that conduct were presumed without further inquiry. Business conduct that was not presumptively unlawful was evaluated under the rule of reason to determine whether, on balance, the conduct at issue should be condemned.

Some of the per se treatment deserved the per se label, and some did not. For practices with categorically unambiguous competitive effects, antitrust per se rules are appropriate. ${ }^{1}$ As our economic understanding of some conduct has improved, some per se rules have been abandoned and replaced by rule of reason analysis. ${ }^{2}$ Supreme Court opinions that went too far in condemning practices that might be procompetitive or competitively neutral have been the

\footnotetext{
* Department of Economics, University of Florida, and Faculty of Law, University of Florida, respectively. The authors have benefited from the advice of several colleagues: H.E. Frech, III, Jeffrey Harrison, Jill Herndon, Herbert Hovenkamp, Keith Hylton, and John Lopatka. Jessica Haynes made valuable contributions to an earlier draft.

${ }^{1}$ Herbert Hovenkamp, The Antitrust Enterprise 115-16 (2005).

2 Andrew I. Gavil, William E. Kovacic, \& Jonathan B. Baker, Antitrust Law in Perspective: Cases, Concepts and Problems in Competition Policy 358 (2002) (noting that after the Sylvania decision "the Court systematically went about the task of dismantling many of the per se rules it had created in the prior fifty years, and increasingly turned to modern economic theory to inform its interpretation and application of the Sherman Act"). As a corollary, the move to a rule of reason analysis has resulted in higher litigation costs because of the complexities involved in the use of that standard. Frank H. Easterbrook, The Limits of Antitrust, 63 TEX. L. REv. 1, 12-13 (1984).
}

78 Antitrust Law Journal No. 2 (2012). Copyright 2012 American Bar Association. Reproduced by permission. All rights reserved. This information or any portion thereof may not be copied or disseminated in any form or by any means or downloaded or stored in an electronic database or retrieval system without the express written consent of the American Bar Association. 
subject of much scholarly criticism. ${ }^{3}$ In many instances, the lower courts undermined the force of those unfortunate precedents by drawing the proverbial "distinction without a difference." 4 This set of conflicting lower court decisions finally attracted the Supreme Court's attention.

We have witnessed the Court's reconsideration of several unfortunate precedents and the consequential demise of per se rules involving boycotts, ${ }^{5}$ vertical price restraints, ${ }^{6}$ and vertical non-price restraints. ${ }^{7}$ Today, the courts analyze each of these practices under the rule of reason.

It is important to identify the goal of antitrust so a rule of reason analysis can proceed in a consistent and logical fashion. ${ }^{8}$ The rule of reason involves more open-ended inquiry than that of a per se analysis, moving antitrust away from rules and toward a standard. It is important, therefore, to have a clear statement of the welfare standard to be employed in promoting the goal of antitrust policy under a rule of reason analysis. In the absence of clear guidance from the Supreme Court, it is left to the discretion of the lower courts which of two standards-consumer welfare or total welfare-will be followed.

\footnotetext{
${ }^{3}$ Christina Bohannan \& Herbert Hovenkamp, IP and Antitrust: Errands into the Wilderness 3-7 (Univ. of Iowa Legal Studies, Research Paper No. 09-16, 2009) (describing the evolution in antitrust thinking in academia, the antitrust agencies, and the courts).

${ }^{4}$ See, e.g., Cont'1 T.V., Inc. v. GTE Sylvania Inc., 433 U.S. 36 (1978) (describing the meaningless distinction made by the Court in Schwinn); see also Khan v. State Oil Co., 93 F.3d 1358 (7th Cir. 1996) (Posner, J.) (offering a tongue-in-cheek refusal to undermine an unwise Supreme Court precedent).

${ }^{5}$ See Nw. Wholesale Stationers, Inc. v. Pac. Stationery \& Printing Co., 472 U.S. 284 (1985) (correcting a popular misconception that boycotts were illegal per se); see also FTC v. Ind. Fed'n of Dentists, 476 U.S. 477 (1986) (declining to treat the refusal to deal as per se unlawful); Joseph P. Bauer, Per Se Illegality of Concerted Refusals to Deal: A Rule Ripe for Reexamination, 79 Colum. L. Rev. 685 (1979) (criticizing the per se treatment of boycotts).

${ }^{6}$ With respect to maximum resale pricing, State Oil Co. v. Khan, 552 U.S. 3 (1997), overruled Albrecht v. Herald Co., 390 U.S. 145 (1968). See generally Roger D. Blair \& John. E. Lopatka, Albrecht Overruled-at Last, 66 AnTitrust L.J. 537 (1998) (providing a legal and economic analysis of maximum resale pricing); Roger D. Blair \& John E. Lopatka, The Albrecht Rule After Khan: Death Becomes Her, 74 Notre Dame L. Rev. 123 (1998) (same). With respect to minimum resale price restraints, Leegin Creative Leather Products, Inc. v. PSKS, Inc., 551 U.S. 877 (2007), overruled Dr. Miles Medical Co. v. John D. Park \& Sons Co., 220 U.S. 373 (1911). See generally Symposium, Antitrust Analysis of Resale Price Maintenance After Leegin, 55 Antitrust Bull. 1 (2010) (describing the controversy spawned by the Leegin decision).

${ }^{7}$ With respect to non-price vertical restraints, Continental T.V., Inc. v. GTE Sylvania Inc., 433 U.S. 36 (1978), overruled United States v. Arnold, Schwinn \& Co., 388 U.S. 365 (1967). See Robert Bork, Vertical Restraints: Schwinn Overruled, 1977 Sup. Cт. Rev. 171 (celebrating the Sylvania decision).

${ }^{8}$ In our view, there can be only a single goal if one values consistency and logic. We make the case for total welfare as the single goal of antitrust.
} 
Robert Bork noted that to effectively implement antitrust law, its goals must be determined. ${ }^{9}$ This guidance is especially important when analyzing conduct under the rule of reason. As we discuss in this article, the goal of antitrust has not been articulated clearly by the Supreme Court. This lack of clear guidance has led to uncertain and inconsistent outcomes under the rule of reason both at the Supreme Court and lower court levels.

The goal of antitrust, as understood by economic analysis, involves a choice of either total welfare or consumer welfare. Total welfare reflects the overall economic surplus from both producers and consumers. In contrast, consumer welfare refers to the surplus that goes only to consumers and does not include producer surplus. Though this distinction may be clear in the abstract, the problem is in its implementation by the courts. As we will explore, the ambiguity arose as a result of Bork's use of the term "consumer welfare" when he meant total welfare. ${ }^{10}$ Not understanding this distinction, the Supreme Court quoted Bork when it suggested that the Sherman Act is a "consumer welfare prescription." 11 Consequently, when courts today use the term "consumer welfare," it is unclear if the term's meaning is literal or if it is being used as Bork intended.

From an economic perspective, the rule of reason inquiry should center on total welfare. If a defendant's conduct reduces total welfare, it would be deemed "unreasonable" and, therefore, should be unlawful; if it does not reduce total welfare, it would not be deemed unreasonable and, therefore, should be lawful. We propose using the Kaldor-Hicks compensation principle to evaluate the impact of various business practices on total welfare. ${ }^{12}$ This approach provides an economically sound methodology for separating objectionable and unobjectionable behavior.

In Part I, we review the Supreme Court's guidance on the standard for conducting a rule of reason analysis. Put simply, the Supreme Court has failed to identify clearly what standard to use. While a case can be made for total welfare as the guiding principle, which is the standard that we advocate, an

\footnotetext{
${ }^{9}$ Robert H. Bork, The Antitrust Paradox: A Policy at War with Itself 50 (1978) [hereinafter Antitrust Paradox].

${ }^{10} \mathrm{Id}$. at 66, 97 (arguing that antitrust law should adopt what Bork terms a "consumer welfare" standard for illegality, but then equating this standard with "total welfare," as that term is understood in economics).

${ }^{11}$ Reiter v. Sonotone Corp., 442 U.S. 330, 343 (1979) (quoting Bork, Antitrust Paradox, supra note 9 , at 66).

${ }^{12}$ See Richard E. Just, Darrell L. Hueth \& Andrew Schmitz, The Welfare Economics of Public Policy: A Practical Approach to Project and Policy Evaluation 32-38 (2004) [hereinafter Welfare ECONOMICS] (discussing the Kaldor-Hicks compensation principle); see also John Hicks, The Foundations of Welfare Economics, 49 Econ. J. 696 (1939); Nicholas Kaldor, Welfare Propositions in Economic and Interpersonal Comparisons of Utility, 49 ECON. J. 549 (1939).
} 
argument also can be made, based upon case law, for consumer welfare. Although the term "consumer welfare" dominates at both the Supreme Court and lower court levels, ${ }^{13}$ a comprehensive reading of the case law suggests that the Court has alternatively suggested either the consumer welfare or total welfare as the correct standard.

In most simple cases, the antitrust welfare standard does not matter. Beyond these simple cases, however, there are more complicated cases for which the welfare standard does matter. The welfare standard matters precisely because one cannot undertake a rule of reason analysis without knowing what standard to apply. Because the rule of reason analysis within antitrust case law has expanded over the past forty years, the need to have a consistent and logical analysis of rule of reason is more important than ever before.

This article introduces the first set of complicated cases where the standard matters in Part II, where we discuss the efficiency trade-off. Next is Part III, in which we analyze the countervailing efficiencies that are accompanied by increased market power flowing from joint ventures or mergers. We also turn our attention to mergers or agreements that turn a monopoly (or a monopsony) into a bilateral monopoly, another instance in which the welfare standard affects whether the particular arrangement should be condemned under the rule of reason. In Part IV, we analyze restraints that have no apparent effect on total welfare but do have pronounced distributive effects. Finally, we close the article with comments in Part V on how to solve the policy dilemma of the implementation of a proper goal of antitrust.

\section{THE RULE OF REASON IN ANTITRUST}

The rule of reason in antitrust law has its foundations in common law. The common law, however, employs a rule of reason analysis that weighs a wider range of total costs and benefits in resolving legal conflicts than is considered under the antitrust laws. As Keith Hylton points out: "The modern rule of reason in antitrust is a narrower test, in the sense that it examines a narrower set of issues." 14 With the demise of many per se rules in antitrust, it has become increasingly important to understand more fully the scope of the rule of reason in antitrust.

For this, one naturally turns to the Supreme Court for instruction. In particular, we seek guidance on the goal of antitrust: to promote total welfare, consumer welfare, or some other objective. Beyond that, we also seek guidance on the scope of the costs and benefits that are cognizable in an antitrust rule of

\footnotetext{
${ }^{13}$ See Herbert J. Hovenkamp, Distributive Justice and Consumer Welfare in Antitrust (Aug. 3, 2011), available at http://ssrn.com/abstract $=1873463$ [hereinafter Distributive Justice].

${ }^{14}$ Keith N. Hylton, Antitrust Law: Economic Theory and Common Law Evolution 116 (2003).
} 
reason inquiry. ${ }^{15}$ The Court, however, has not been as helpful as one might wish since the Chicago revolution.

It is clear that the rule of reason is aimed at determining the competitive effects of a business practice under review. In order to implement the rule of reason, however, it is necessary to know what "value" or "values" the antitrust laws should promote. ${ }^{16}$ Although some support can be found for other values, ${ }^{17}$ the most prominent are consumer welfare and total welfare. In many, if not most, circumstances, judgments on reasonableness will be invariant across these two goals. There are, however, restraints that may be reasonable on total welfare grounds but unreasonable on consumer welfare grounds. Consequently, it is important to identify the policy goal being pursued.

One factor that motivates the study of the appropriate welfare standard has been the continued divergence within the academy and case law on the standard. Posner, however, suggests that there is a single belief on this standard:

Almost everyone professionally involved in antitrust today-whether as litigator, prosecutor, judge, academic, or informed observer-not only agrees that the only goal of the antitrust laws should be to promote economic welfare, but also agrees on the essential tenets of economic theory that should be used to determine the consistency of specific business practices with that goal. ${ }^{18}$

In Posner's formulation, this goal is based upon a total welfare calculation. ${ }^{19}$ Though Posner is correct in stating the majority position, it is interest-

\footnotetext{
${ }^{15}$ In National Society of Professional Engineers v. United States, 435 U.S. 679 (1978), Justice Stevens, writing for the majority, appeared to limit the inquiry to costs and benefits in the market in which the restraint occurs, i.e., the Court relied on a partial equilibrium analysis. This means that effects-good and bad-in related markets are irrelevant to the inquiry. If, for example, there were a restraint in the beef market, the impact in the markets for substitutes (chicken, pork, tofu) or the markets for complements (potatoes, condiments) would not be considered. Nor would the impacts in the input markets (cattle, labor) be considered. Professional Engineers' narrowing of the inquiry clearly makes it more manageable, but it does not necessarily yield the socially optimal results from an economic perspective. This, of course, assumes that we do not consider non-market effects and externalities. See Richard M. Brunell, The Social Costs of Mergers: Restoring "Local Control" as a Factor in Merger Policy, 85 N.C. L. Rev. 149 (2006); Christopher R. Leslie, Achieving Efficiency Through Collusion: A Market Failure Defense to Horizontal Price-Fixing, 81 CALIF. L. Rev. 243 (1993).

${ }^{16}$ See Robert H. Bork, Legislative Intent and the Policy of the Sherman Act, 9 J.L. \& Econ. 7 (1966) [hereinafter Legislative Intent].

${ }^{17}$ See, e.g., Richard Hofstadter, What Happened to the Antitrust Movement, in The ParanoID Style in American Politics (1965); William Letwin, Law and Economic Policy in America: The Evolution of the Sherman Antitrust Act (1965); Rudolph J.R. Peritz, Competition Policy in America, 1888-1992 (1996); Hans B. Thorelli, The Federal Antitrust Policy: Origination of an American Tradition (1955); Thomas J. DiLorenzo, The Origins of Antitrust: An Interest-Group Perspective, 5 InT'L Rev. L. \& Econ. 73 (1985).

${ }^{18}$ Richard A. Posner, Antitrust Law ix (2d ed. 2001).

${ }^{19}$ Id. at 23-24.
} 
ing to note that his position has been taken primarily by economists and law professors who draw from the Chicago School heritage. ${ }^{20}$

The Supreme Court has left ambiguous whether consumer or total welfare should be used as the appropriate standard. Many of the Court's opinions are confusing because of the effects of Bork's powerful influence. ${ }^{21}$ In 1966, Bork analyzed the legislative intent of the Sherman Act. ${ }^{22} \mathrm{He}$ argued that economic efficiency should be the guiding principle, which means total welfare, but he called this "consumer welfare." This was a poor choice of words. Over 100 court cases today cite to Bork explicitly when referring to the "consumer welfare" goal of the antitrust laws, making it difficult to know precisely what the court means when it refers to "consumer welfare." ${ }^{23}$ These cases range from Supreme Court cases (most recently Leegin ${ }^{24}$ ) to lower court decisions.

The desire to promote consumer welfare over total welfare has been made on democratic grounds ${ }^{25}$ and on similar grounds of supporting the political bargain of antitrust. ${ }^{26}$ For example, Robert Lande has argued for a consumer welfare standard as a tie-breaker when there is a difference between consumer and total welfare. In his earliest work on the topic he argued for legal rules in mergers that would "incorporat[e] both efficiency and distributive considerations into the formulation of merger guidelines." ${ }^{27}$ In some circumstances, this is without problem. In others, wealth distribution would assume primacy

20 See e.g., Massimo Motta, Competition Policy, Theory and Practice (2004); Robert H. Bork, The Goals of Antitrust Policy, 57 Am. Econ. Rev. 242 (May 1967); Dennis W. Carlton, Does Antitrust Need to Be Modernized?, 21 J. Econ. Persp., Summer 2007, at 155; Kenneth G. Elzinga, The Goals of Antitrust: Other than Competition and Efficiency, What Else Counts?, 125 U. PA. L. Rev. 1191 (1977); Joseph Farrell \& Michael L. Katz, The Economics of Welfare Standards in Antitrust, 2 Competition Pol'y Int'L 3 (2006); Alan J. Meese, Debunking the Purchaser Welfare Account of Section 2 of the Sherman Act: How Harvard Brought Us a Total Welfare Standard and Why We Should Keep It, 85 N.Y.U. L. Rev. 659 (2010); Richard A. Posner, The Chicago School of Antitrust, 127 U. PA. L. Rev. 925, 932 (1979); Donald F. Turner, The Scope of Antitrust and Other Economic Regulatory Policies, 82 Harv. L. Rev. 1207, 1208-09 (1969).

${ }^{21}$ Barak Y. Orbach, The Antitrust Consumer Welfare Paradox, 7 J. Competition L. \& Econ. 133, 134-35 (2011).

${ }^{22}$ Bork, Legislative Intent, supra note 16.

${ }^{23}$ A Westlaw search in the "ALLFEDS" and "SCT" databases finds that there are 18 Supreme Court cases and 180 total federal court cases that cited to Bork's Antitrust Paradox. Most of these cases, however, do not seem to appreciate the context in which Bork wrote.

${ }^{24}$ Leegin Creative Leather Prods., Inc. v. PSKS, Inc., 551 U.S. 877 (2007).

${ }^{25}$ John B. Kirkwood \& Robert H. Lande, The Fundamental Goal of Antitrust: Protecting Consumers, Not Increasing Efficiency, 84 Notre Dame L. Rev. 191, 237 (2008).

${ }^{26}$ Jonathan B. Baker, Competition Policy as a Political Bargain, 73 Antitrust L.J. 483, 486 (2006). We do not believe that consumer welfare is necessarily merely distributive. Once a court chooses a consumer welfare standard, it tries to maximize consumer surplus within the consumer welfare approach (but remains willing to sacrifice productive efficiency).

${ }^{27}$ Robert H. Lande, Wealth Transfers as the Original and Primary Concern for Antitrust: The Efficiency Interpretation Challenged, 34 Hastings L.J. 65, 148-49 (1982). 
based upon Congressional intent. ${ }^{28}$ Lande also combines small business protection and consumer welfare goals, although he notes the primacy of consumer welfare in this calculation..$^{29}$

Based on the somewhat ambiguous instructions from the Supreme Court, it is unclear whether a rule of reason inquiry should focus on consumer welfare or on total welfare. This lack of clarity did not need to be the case. Had the Court consistently followed the economic logic of Continental T.V., Inc. v. GTE Sylvania Inc, we would not have the ambiguity that exists today. ${ }^{30}$ Justice White's concurring opinion characterizes the position of the Court in Sylvania as "view[ing] the Sherman Act as directed solely to economic efficiency ...." ${ }^{31}$ Since White cited Bork when referring to economic efficiency, one may infer that he meant total welfare.

Unfortunately, the Court subsequently decided Brunswick ${ }^{32}$ that very year using a different logic from what it had set out in Sylvania. In his Brunswick opinion, Justice Marshall discussed the Congressional intent of the Sherman Act. ${ }^{33}$ The plaintiff in Brunswick sought treble damages for injustices that flowed from enhanced lawful competition provided by Brunswick. Marshall pointed out that awarding lost profits to the competitor was not in the spirit of the antitrust laws. Marshall found support for this position in the legislative debates on treble damages. In these debates, the legislative history suggested that the trebling of damages provided individual consumers with a remedy against the anticompetitive behavior of firms. Thus, Brunswick seems to favor a consumer welfare standard. Our inference here is somewhat tentative, however, because Brunswick dealt with cognizable damages rather than the lawfulness of Brunswick's business practices.

Two years later, in Reiter, ${ }^{34}$ the central issue was whether consumers had standing to sue for overcharge damages. Following Sylvania, the Court cited Bork's consumer welfare standard. In this case, however, it is much less clear

\footnotetext{
${ }^{28} \mathrm{Id}$. at 151 . This interpretation of the legislative history is not uniform. Bork argued that the Sherman Act was based on efficiency. Bork, Antitrust Paradox, supra note 9, at 66. Some scholars, however, reject this view as not supported by the legislative history. See Orbach, supra note 21 , at 136 (providing a literature review). Hovenkamp has argued, instead, that the legislative history of the Sherman Act reflects competitor concerns. Herbert Hovenkamp, Antitrust's Protected Classes, 88 Mich. L. Rev. 1, 28-29 (1988) ("The principal victims of the trust movement of the 1880s - certainly of the trusts that appeared most frequently on Congress' hit listwere inefficient small firms, rather than consumers. Competitors were the principal protected class of the Sherman Act.").

${ }^{29}$ Kirkwood \& Lande, supra note 25, at 210.

30433 U.S. 36 (1977).

${ }^{31} I d$. at 69.

${ }^{32}$ Brunswick Corp. v. Pueblo Bowl-O-Mat, Inc., 429 U.S. 477 (1977).

${ }^{33} \mathrm{Id}$. at 488.

${ }^{34}$ Reiter v. Sonotone Corp., 442 U.S. 330 (1979).
} 
that the Court was really concerned with the allocative inefficiency that puts Bork's consumer welfare standard in line with a total welfare standard. Most of the opinion centered on the standing of final consumers under Section 4 of the Clayton Act. In explaining why consumers of final goods had standing, the Court observed that:

Respondents engage in speculation in arguing that the substitution of terms ... [in $\S 4$ of the Clayton Act] for the broader language originally proposed by Senator Sherman was clearly intended to exclude pecuniary injuries suffered by those who purchase goods and services at retail for personal use .... On the contrary, they [the Congressional floor debates] suggest that Congress designed the Sherman Act as a "consumer welfare prescription." Certainly the leading proponents of the legislation perceived the treble-damages remedy of what is now $\S 4$ as a means of protecting consumers from overcharges resulting from price fixing. ${ }^{35}$

The second sentence, which incorporates Bork's consumer welfare prescription, has been used to suggest that the Court recognized a total welfare goal. ${ }^{36}$ The context of its use, however, speaks more to consumer welfare than total welfare.

Similarly, in the Court's NCAA opinion, ${ }^{37}$ a citation to Bork's consumer welfare principle is muddled by the Court's discussion of consumer welfare. In this case, the University of Oklahoma and the University of Georgia brought suit against the NCAA for fixing the price of telecasts of football games and limiting the number of games that could be televised. While the first charge was per se illegal, the limits on the number of games that could be broadcast were examined under the rule of reason. The Supreme Court focused on the impact of such restraints on consumers. In particular, the Court found that "both [price and output] are unresponsive to consumer preference. This . . p point is perhaps the most significant, since Congress designed the Sherman Act as a 'consumer welfare prescription." "' 38

Likewise, in the Court's Professional Engineers decision, ${ }^{39}$ the language and focus of the opinion are also ambiguous on the question of which welfare standard the Court intended to employ. The Court did not find it necessary to consider the actual effects of the restraint on competition, but instead defended the position that competition should determine both the optimal price

\footnotetext{
${ }^{35}$ Id. at 343-44 (citations omitted).

${ }^{36}$ Douglas H. Ginsburg, Judge Bork, Consumer Welfare, and Antitrust Law, 31 HARv. J.L. \& Pub. Pol'y 449, 452 (2008).

${ }^{37}$ NCAA v. Bd. of Regents of Univ. of Okla., 468 U.S. 85 (1984).

${ }^{38} \mathrm{Id}$. at 88 (quoting Bork, Antitrust Paradox, supra note 9, at 66). This is actually a reference to Bork's total welfare standard, but the discussion is on true consumer welfare.

${ }^{39}$ Nat'l Soc'y of Prof'l Eng'rs v. United States, 435 U.S. 679 (1978).
} 
and level of product quality. This focus on competition may suggest that the Court's intention was to promote total welfare rather than consumer welfare.

In 1986, the Court again had an opportunity to address the role of a professional association in Indiana Federation of Dentists. ${ }^{40}$ The opinion similarly relied on the ability of competition to induce the best possible outcomes. To some extent, the following statement clarifies what "value" is in play:

A refusal to compete with respect to the package of services offered to customers, no less than a refusal to compete with respect to the price term of an agreement, impairs the ability of the market to advance social welfare by ensuring the provision of desired goods and services to consumers at a price approximating the marginal cost of providing them. ${ }^{41}$

Thus, in Indiana Federation of Dentists, the Supreme Court explicitly acknowledges the importance of total welfare.

Yet, this explicit embrace of total welfare has waned in recent years within the case law. ${ }^{42}$ In Weyerhaeuser, ${ }^{43}$ for instance, the Court discussed issues of predatory buying and its welfare impact. This decision illustrates that the $\mathrm{Su}$ preme Court still does not quite understand the difference between welfare standards. The Court in Weyerhaeuser cites to Bork's Antitrust Paradox as to why recoupment is necessary for the predation scheme to make economic sense. Yet, the decision suggests a literal reading of consumer welfare-the Weyerhaeuser Court revisited the logic of Brooke Group" to note that "a failed predatory-bidding scheme can be a 'boon to consumers' in the same way that we considered a predatory-pricing scheme to be." ${ }^{45}$ The Court further notes that predatory bidding and monopsony may not have an effect on consumers, merely an effect on upstream producers and, for this reason, the same legal rules that apply to predatory pricing should apply in the predatory buying context. ${ }^{46}$

Applying the same rule to predatory pricing and predatory buying would make sense if the two situations were the same. The economics of predatory

\footnotetext{
${ }^{40}$ FTC v. Ind. Fed'n of Dentists, 476 U.S. 447, 457 (1986). In this case, the dentists collectively refused to provide information to dental insurers that would be used to assess the appropriateness of the proposed dental care. The dentists argued that such review would impair the quality of care.

${ }^{41}$ Id. at 459 (emphasis added).

${ }^{42}$ Hovenkamp, Distributive Justice, supra note 13, at 11.

${ }^{43}$ Weyerhaeuser Co. v. Ross-Simmons Hardwood Lumber Co., 549 U.S. 312 (2007).

${ }^{44}$ Brooke Group Ltd. v. Brown \& Williamson Tobacco Corp., 509 U.S. 209 (1993).

${ }^{45}$ Weyerhaeuser, 549 U.S. at 324-25.

${ }^{46}$ Id.; see also J. Thomas Rosch, Monopsony and the Meaning of "Consumer Welfare": A Closer Look at Weyerhaeuser, 2007 Colum. Bus. L. Rev. 353 (2007).
} 
pricing and predatory buying, however, are not the same. ${ }^{47}$ By treating predatory pricing and predatory bidding the same way, the Court created a standard that was underinclusive, effectively allowing a safe harbor for the predatory buyer. This rule can negatively impact total welfare..$^{48}$

The Court's most recent expression of its welfare standard can be found in Leegin. ${ }^{49}$ Transcripts of the proceedings, as well as the language of the Court's opinion, make it clear that the Court supports a consumer welfare standard. ${ }^{50}$ The majority opinion includes an unambiguous statement that the Sherman Act and antitrust policy are intended to serve the "interests of consumers." ${ }^{51}$ It states more fully: "The Sherman Act seeks to maintain a marketplace free of anticompetitive practices .... The law assumes that such a marketplace ... will tend to bring about the lower prices, better products, and more efficient production processes that consumers typically desire." ${ }_{52}$

Overall, in surveying the Supreme Court's modern opinions, a crystal clear identification of antitrust's goal is as elusive as ever. In the most recent cases, the Court has shied away from some of its earlier misadventures, such as protecting small locally owned businesses. ${ }^{53}$ Instead, the remaining confusion is choosing between total welfare and consumer welfare as the central goal of antitrust. The Supreme Court seems to shift between consumer welfare and total welfare in determining reasonableness. Most of the Court's opinions arguably favor consumer welfare. Even some opinions that explicitly cite Bork's "consumer welfare" principle, which actually means total welfare, focus on the impact on consumers, suggesting a perspective more consistent with consumer welfare than with total welfare.

It is difficult to say just what the Court really means due to its misuse of terms that have precise meaning in economics. The resulting imprecision is unfortunate because antitrust enforcement would be easier if we fully understood what goal the judiciary is pursuing. As an economic matter, we believe that the reasonableness of a business practice should be determined by its

\footnotetext{
${ }^{47}$ See Roger D. Blair \& John E. Lopatka, Predatory Buying and the Antitrust Laws, 2008 Utah L. Rev. 415 (describing in detail the complexity of predatory buying).

48 Roger D. Blair \& Jeffrey L. Harrison, Monopsony in Law and Economics 77 (2010).

${ }^{49}$ Leegin Creative Leather Prods., Inc. v. PSKS, Inc., 551 U.S. 877 (2007).

${ }^{50}$ An exchange between Justice Scalia and the plaintiff's lawyer, Mr. Olson, addresses this directly. "Justice Scalia: Is it the sole object of the Sherman Act to produce low prices? Mr. Olson: No. Justice Scalia: I thought it was consumer welfare. Mr. Olson: Yes, yes, it is. Justice Scalia: And I thought some consumers would prefer more service at a higher price." Linda Greenhouse, Justices Hear Arguments About Pacts on Pricing, N.Y. Times, Mar. 27, 2007, at C1.

${ }^{51}$ Leegin, 551 U.S. at 904.

$52 \mathrm{Id}$. at 909.

${ }^{53}$ See, e.g., Brown Shoe Co. v. United States, 370 U.S. 294, 344 (1962).
} 
impact on total welfare. But we recognize that a credible case-albeit an imperfect one-can be made for consumer welfare. In many cases, using consumer welfare and total welfare lead to the same result. However, complications and inconsistencies do exist in some cases analyzed under the rule of reason and related merger law.

\section{THE EFFICIENCY TRADE-OFF}

In 1968, Oliver Williamson in a path-breaking article discussed the need to weigh the benefits of improved efficiency against the costs of allocative inefficiency. ${ }^{54} \mathrm{~A}$ discussion of the Williamson trade-off is essential to understanding the implications of using a consumer or a total welfare standard given that that the Williamson trade-off was the very basis of Bork's efficiency analysis. ${ }^{55}$ We note that the lessening of competition legal standard under Clayton Section 7 is not precisely the same as a rule of reason analysis as applied by the courts under the Sherman Act. However, from an economic standpoint, the analysis of mergers illustrates the confusion that results from not knowing which welfare standard to use. This analysis of merger efficiencies is also applicable to joint ventures. Unlike mergers, joint ventures are governed by Sherman Section 1 and hence a rule of reason analysis. ${ }^{56}$

In many antitrust cases, because consumer welfare and total welfare move in the same direction, the outcome of a rule of reason analysis will be the same regardless of what standard is used. ${ }^{57} \mathrm{We}$ focus our analysis primarily on merger-specific cases analyzed under Section 7 of the Clayton Act, where the analysis is similar to the rule of reason, and where the outcome of the substantive analysis may be different depending on whether a consumer welfare or total welfare standard is used.

In this section, we examine the Williamson trade-off that takes place when merger-specific efficiencies are accompanied by an increase in monopoly power. There are some instances in which a business practice improves efficiency, i.e., reduces costs of production and/or distribution. If the practice does not enhance market power, the cost savings will be passed on to some extent to consumers in the form of lower prices. ${ }^{58}$ In these cases, there is no complication, and the antitrust policy should be one of benign neglect since

\footnotetext{
${ }^{54}$ Oliver E. Williamson, Economies as an Antitrust Defense: The Welfare Trade-Offs, 58 Ам. ECON. Rev. 18 (1968).

${ }^{55}$ Bork, Antitrust Paradox, supra note 9, at 107-10 (suggesting that Williamson's tradeoff may illustrate all antitrust issues).

56 See 11 Herbert HovenKamp, Antitrust Law II 1910-12 (2d. ed. 2005).

${ }^{57}$ The standard models of monopoly and monopsony are available in most microeconomics textbooks. See, e.g., Jeffrey Perloff, Microeconomics 353-59, 533-39 (6th ed. 2011).

${ }^{58}$ In the extreme case, where the market is perfectly competitive, the firm will not pass on any firm-specific efficiency.
} 
both consumer welfare and total welfare are increased by the business practice.

In some instances, however, the merger-specific efficiency is accompanied by enhanced market power. This may still result in greater output and lower prices and, therefore, could increase both consumer welfare and total welfare. The complication arises when there is a cost reduction due to the efficiency accompanied by an increase in market power that leads to a price increase above the previous level. This situation creates a need to weigh the benefits of improved efficiency against the costs of allocative inefficiency. The same analysis applies to all joint ventures and agreements that are necessary to realize the efficiency.

\section{A. Efficiency-Enhancing Joint Ventures and Mergers Among Sellers}

The trade-off analyzed by Williamson illustrates the complications that may accompany efficiency-enhancing agreements, joint ventures, and horizontal mergers. ${ }^{59}$ In Figure 1, the pre-agreement price and quantity, $\mathrm{P}_{1}$ and $\mathrm{Q}_{1}$, respectively, are determined by the equality of demand (D) and the competitive supply, which is shown as $\mathrm{MC}_{1}=\mathrm{AC}_{1}$. The model assumes that industry marginal cost $\left(\mathrm{MC}_{1}\right)$ and average cost $\left(\mathrm{AC}_{1}\right)$ are constant. The joint venture increases efficiency, as reflected in the decrease in costs from $\mathrm{MC}_{1}=\mathrm{AC}_{1}$ to $\mathrm{MC}_{2}=\mathrm{AC}_{2}$. If market power does not increase as a result of the joint venture, the cost savings will be passed on to consumers. ${ }^{60}$ The price will fall to $\mathrm{P}_{2}$ and the quantity consumed will rise from $\mathrm{Q}_{1}$ to $\mathrm{Q}_{2}$. In this case, the joint venture raises no antitrust policy concerns since the welfare effects are unambiguously positive: both consumer welfare and total welfare increase.

Complications arise when market power increases due to an efficiency-enhancing joint venture or merger. In Figure 1, suppose that the joint venture leads to the same cost savings, but that the exercise of the resulting market power leads to an increase in price from $\mathrm{P}_{1}$ to $\mathrm{P}_{3}$ with a corresponding decrease in quantity from $\mathrm{Q}_{1}$ to $\mathrm{Q}_{3}$. From the consumer's perspective, the transaction appears to be clearly undesirable. The price paid rises and the consumer does not appear to enjoy any of the benefits from the cost reduction. The allocative inefficiency flowing from the exercise of market power causes consumer surplus to fall from area $a c \mathrm{P}_{1}$ to area $\mathrm{abP}_{3}$. If the lawfulness of the

\footnotetext{
${ }^{59}$ William M. Landes, Optimal Sanctions for Antitrust Violations, 56 U. ChI. L. Rev. 652 (1983) (addressing a similar problem when a horizontal price-fixing cartel reduces transaction costs while increasing price).

${ }^{60}$ Due to the perfectly elastic competitive supply curve, all of the cost saving is passed on to consumers when the market remains competitive. If the supply curve were positively sloped, not all of the cost saving would be passed on, but output would still rise, and price would still fall.
} 


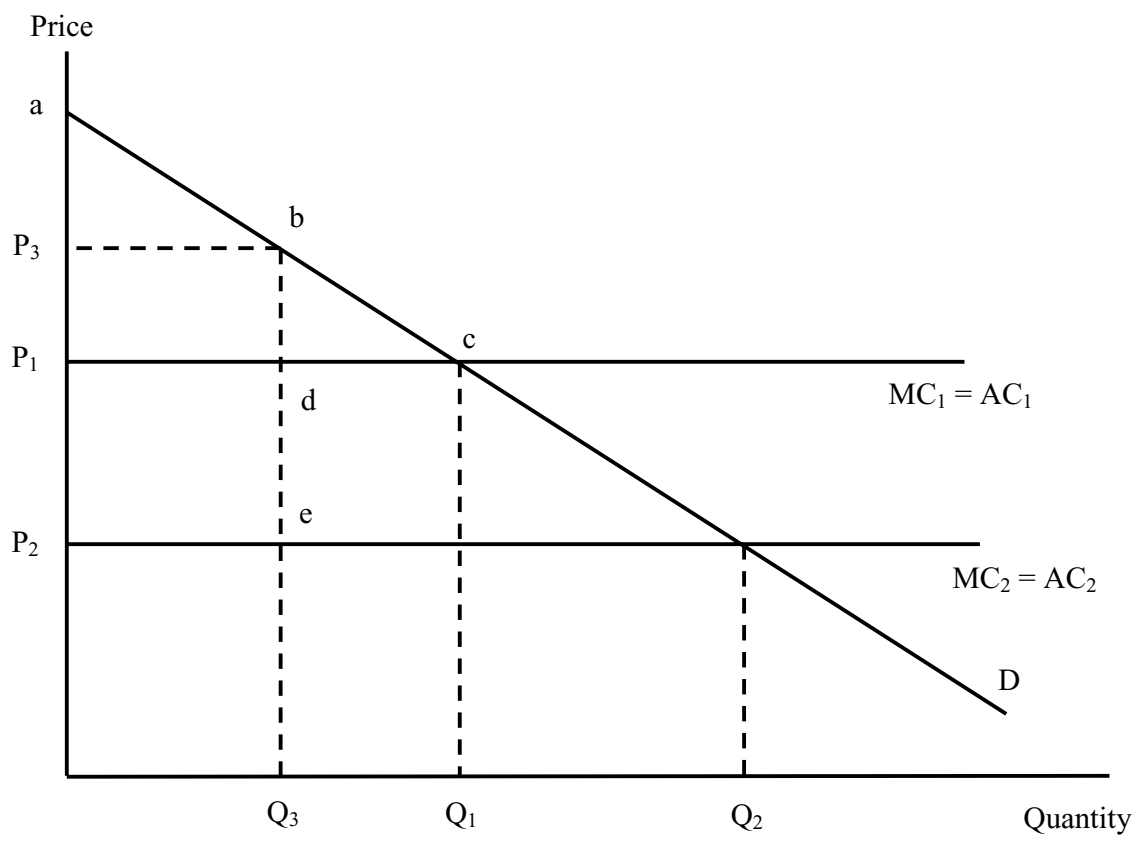

FIGURE 1: EFFICIENCY-ENHANCING JOINT VENTURES AND MERGERS

agreement, joint venture, or merger is determined solely on the basis of consumer welfare in this market, it would be unlawful. If one looks at this joint venture from a total welfare perspective, however, there are two important observations worth making. First, whether total welfare rises or falls depends on the relative magnitudes of the allocative inefficiency and the cost saving. In Figure 1, the allocative inefficiency is given by the triangular area bcd. The profit to the sellers is equal to the rectangle $\mathrm{P}_{3} \mathrm{beP}_{2}$. Part of this, area $\mathrm{P}_{3} \mathrm{bdP}_{1}$, is a transfer from consumers to producers, and the remainder, the rectangle $\mathrm{P}_{1} \mathrm{deP}_{2}$, represents the cost savings. As Figure 1 is drawn, the cost saving appears to be larger than the allocative inefficiency. In that event, the joint venture should not be barred on total welfare grounds because the benefits of the cost saving outweigh the allocative inefficiency. The merger is KaldorHicks efficient because the winners (the producers) could compensate the losers (the consumers) and still be better off. ${ }^{61}$

But this need not always be the case. When the allocative inefficiency outweighs the cost saving, the joint venture reduces both consumer welfare and

${ }^{61}$ See Thomas J. Miceli, The Economic Approach to Law 1-7 (2d ed. 2009) (discussing Kaldor-Hicks efficiency); Just ET AL., Welfare Economics, supra note 12, at 32-38 (same). 
total welfare. The joint venture is inefficient on the Kaldor-Hicks criterion because the winners cannot profitably compensate the losers. Such a joint venture or merger should be forbidden. Since we cannot presume that the net effect of an efficiency-enhancing agreement among rival sellers will inevitably be positive or negative, we need reliable estimates of the cost savings as well as of the allocative inefficiency. This is particularly daunting for proposed mergers because both estimates are needed before the merger is actually consummated.

Merger simulations have proven useful in many instances. ${ }^{62}$ But merger simulations do not appear to be well-equipped to deal with the problem at hand. ${ }^{63}$ The typical merger simulation predicts price effects before a merger has actually occurred. These simulations, however, use estimated demand elasticities and assumptions about the conduct of the firms to back out calculations of a firm's marginal cost. This makes it difficult to incorporate the cost savings and measure the potential allocative inefficiency. It is difficult for the analyst to estimate the cost savings a merged firm is apt to realize without very detailed cost data and very specialized institutional knowledge. Without specific cost estimates, merger simulation does not address the effect of efficiency. Moreover, estimating the potential allocative inefficiency is complicated by the fact that a firm's post-merger conduct may differ substantially from its pre-merger conduct. Consequently, it is doubtful that merger simulations are the answer.

There is a second observation regarding the cost savings that should be made. Even if one's focus is solely on consumer welfare, the cost savings benefit consumers generally. These cost savings do, of course, improve the profits of the sellers in this market. But it would be a mistake to dismiss these cost savings as of no consequence to consumers. ${ }^{64}$ The sellers' costs fall because fewer of society's scarce resources are needed to produce the output

${ }^{62}$ Gregory J. Werden \& Luke M. Froeb, Simulation as an Alternative to Structural Merger Policy in Differentiated Products Industries, in The Economics of The Antitrust Process (Malcolm B. Coate \& Andrew N. Kleit eds., 1996).

${ }^{63}$ Gregory J. Werden, Simulating the Effects of Differentiated Products Mergers: A Practitioners' Guide, in Strategy and Policy in the Food System: Emerging Issues 95-110 (Julie A. Caswell \& Ronald W. Cotterill eds., 1996); Oliver Budzinski \& Arndt Christiansen, The Oracle/PeopleSoft Case: Unilateral Effects, Simulation Models and Econometrics in Contemporary Merger Control, 34 Legal Issues of Econ. InTEgration 133 (2007); Dennis W. Carlton, The Relevance for Antitrust Policy of Theoretical and Empirical Advances in Industrial Organization, 12 Geo. Mason L. Rev. 47 (2003); Gregory J. Werden \& Luke M. Froeb, The Effects of Mergers in Differentiated Product Industries: Logit Demand and Merger Policy, 10 J.L. Econ. \& ORG. 407 (1994).

${ }^{64} \mathrm{We}$ are not counting the cost savings twice. One may dismiss them as beneficial to the sellers, but they should be considered for their benefits to consumers. 
being sold. ${ }^{65}$ These resources are then available to produce goods and services in other markets. The consumer benefits flowing from these cost savings may be diffused throughout the economy, but they exist nonetheless. ${ }^{66}$

\section{B. Some Numerical Examples}

The following numerical examples are purely hypothetical. These examples are intended to illustrate the relationship between cost savings and changes in welfare. First, we show that a cost saving can offset a fairly large price increase. Second, we illustrate how large a cost saving would have to be to prevent a price increase that would reduce consumer welfare. The third example illustrates the importance of the pre-merger or pre-agreement market structure. Finally, the fourth example illustrates the necessary cost efficiencies for joint ventures or mergers that fall short of monopoly.

Example 1: Suppose that the demand is given by $\mathrm{P}=100-0.001 \mathrm{Q}$ and that the pre-merger marginal and average costs are constant and equal to 25 . The competitive solution involves a price of 25 and a quantity of 75,000 . In this case, consumer surplus is equal to $1 / 2 \times(75) \times(75,000)$, which is $2,812,500$. Producer surplus is zero because price is equal to average cost.

Now, suppose that there is a merger to monopoly that reduces average and marginal cost to 10. Profit maximization by the monopolist leads to a price of 55 , which is an increase of 30 . The quantity falls to 45,000 , which is a decrease of $30,000 .{ }^{67}$ At the monopoly solution, the consumer surplus is $1 / 2 \times(45) \times(45,000)$, which is $1,012,500$. Profit for the monopolist would then be $(45) \times(45,000)$, which equals $2,025,000$. The sum of consumer surplus and profit is $3,037,500$, which is larger than the pre-merger consumer surplus. Consequently, the merger is Kaldor-Hicks efficient, because the winner (the monopolist) could compensate the loser (consumers) and still have profits left over. It is also instructive to note that allocative inefficiency is $1 / 2 \times(55-25) \times(75,000-45,000)$, which is 450,000 , while the cost saving is $(25-10) \times(45,000)$, which is 675,000 . Even though the price increase was twice the cost saving, total welfare increased. ${ }^{68}$

\footnotetext{
${ }^{65} \mathrm{We}$ are not referring to the resources not being used because output has been reduced from $\mathrm{Q}_{1}$ to $\mathrm{Q}_{3}$. We are instead referring to the resources now needed to produce $\mathrm{Q}_{3}$.

${ }^{66}$ Paul A. Pautler, The Effects of Mergers and Post-merger Integration: A Review of Business Consulting Literature (Jan. 21, 2003), available at http://www.ftc.gov/be/rt/businesreviewpaper .pdf (surveying the literature on efficiencies).

${ }^{67}$ The monopolist will produce where marginal revenue equals marginal cost: $100-0.002 \mathrm{Q}=10$, which yields $\mathrm{Q}=45,000$. Substitution into the demand function yields a price of 55.

${ }^{68}$ The hypothetical cost savings amounted to 60 percent of the pre-merger cost. This, of course, is enormous, but the point is that the merger to monopoly can be socially beneficial.
} 
Example 2: In the second example, we focus on consumer welfare rather than total welfare in order to get a sense of how large a cost reduction must be to cause no harm to consumers in the face of a joint venture or merger to monopoly. Suppose that consumer demand can be written as the following linear function, $\mathrm{P}=100-0.1 \mathrm{Q}$, where $\mathrm{P}$ and $\mathrm{Q}$ represent price and quantity, respectively, and marginal cost prior to the merger or joint venture is equal to 40. If there are two firms that behave as Cournot duopolists ${ }^{69}$ the price will be 60 , and the quantity consumed will be $400 .{ }^{70}$ If the two firms form a joint venture or merge to monopoly, marginal cost must fall from 40 to 20 to prevent a price increase..$^{71}$ Thus, a 50 percent reduction in marginal cost is needed to avoid a reduction in consumer welfare as measured by consumer surplus.

Example 3: This example illustrates that merging to monopoly is apt to require substantial-perhaps even extraordinary-economies to offset the consequences of the increase in monopoly power. ${ }^{72}$ As the pre-agreement market structure moves closer to a competitive market structure, the cost reduction necessary to avoid consumer harm grows substantially. For three Cournot rivals, the necessary decrease in marginal cost is 75 percent. ${ }^{73}$ For four Cournot rivals, it would be 90 percent. For a pre-agreement market structure with five Cournot rivals, marginal cost would have to fall to zero to avoid any harm to consumers. The actual efficiency that an agreement, joint venture, or merger would generate will vary from case to case.

Example 4: The examples above all involve a change in market structure that results in a complete monopoly. Less extreme consolidations will not demand such substantial cost efficiencies to avoid consumer harm. Suppose that there were five Cournot rivals prior to the joint venture or merger. Given the same demand and cost conditions, price would be 50 and output would be 500. If an agreement, joint venture, or merger resulted in four Cournot competitors, the cost reduction would only have to be 2.5 , which is only a 6.25

\footnotetext{
${ }^{69}$ Cournot duopolists compete by setting their quantities and letting price be determined by demand. Perloff, supra note 57, at 447.

${ }^{70}$ It can be shown that the Cournot duopoly output will be $2 / 3$ of the competitive output. Given the demand and cost assumptions, the competitive output is 600. Price in the Cournot duopoly example is determined by substituting $\mathrm{Q}=400$ into the demand function. $I d$. at 452 .

${ }^{71}$ To show this, we solve for consumer surplus in the pre-merger period. $\mathrm{CS}_{1}=1 / 2 \times(100-$ $60) \times 400=8,000$. Then, we compare this to the post-merger calculation of consumer surplus, $\mathrm{CS}_{2}=1 / 2 \times(100-\mathrm{MC})^{2} / 0.4$. Setting $\mathrm{CS}_{1}=\mathrm{CS}_{2}$, we can solve for the value of MC that will leave consumer surplus unchanged. $1 / 2 \times(100-\mathrm{MC})^{2} / 0.4=8,000$. Therefore, $\mathrm{MC}=20$ will leave consumer surplus the same.

${ }^{72}$ In fact, there has never been a decided merger case that explores what kind of extraordinary efficiencies might be contemplated, as articulated in FTC v. H.J. Heinz Co., 246 F.3d 708, 720-22 (D.C. Cir. 2001).

${ }^{73}$ In this case, pre-agreement output would be $\mathrm{Q}=3 / 4 \times(600)=450$. Now, we solve: $100-(0.2 \times 450)=$ MC. The solution to this equation is 10 , or 25 percent of 40 .
} 
percent reduction. ${ }^{74}$ In the real world, this may still be a substantial efficiency gain, but it is far less than the efficiencies necessary to justify monopoly.

\section{Efficiency-Enhancing Joint Ventures and Mergers AMONG Buyers}

A similar analysis applies to efficiency-enhancing agreements, joint ventures, and mergers among buyers. ${ }^{75}$ When formerly competing buyers merge, concentration on the buying side of the relevant market necessarily increases, with the extent of the increase depending on the relative sizes of the merging firms ${ }^{76}$ If the merger yields merger-specific efficiencies, one of three things is likely to happen. First, if the market is unconcentrated before and after the merger, this sort of merger poses no antitrust concerns. Given the pre-merger and post-merger market structure, this merger would not attract much attention from the antitrust enforcement agencies.

Second, the merger could alter the market structure in such a way that noncompetitive pricing would occur, but the post-merger price would still be above the pre-merger price due to substantial efficiencies. In this case, the efficiencies cause the derived demand to shift enough so that the post-merger monopsony price exceeds the pre-merger competitive price. If these efficiencies are merger-specific, then the merger should still be applauded because suppliers benefit from higher prices and greater sales. The fact that prices are below the new competitive level is bothersome, but suppliers are still better off on balance. By assumption, the efficiencies are not obtainable without the merger, so society is better off with the merger than without it.

The third and most interesting possibility involves the Williamson trade-off as adapted to monopsony. In this case, merger-specific efficiencies reduce the transaction costs of the buyers, but the increase in market concentration is sufficient to produce a price and quantity below the pre-merger level.

More specifically, we are considering the situation in which the buyers purchase an intermediate good that is used to produce a final good. The de-

\footnotetext{
74 To avoid consumer harm, $4 / 5$ of the competitive output must be 500 . Thus, the pre-agreement competitive output must be $4 / 5 \mathrm{Q}=500$ or $\mathrm{Q}$ equal to 625 . Thus, we solve $100-(0.1 \times 625)=\mathrm{MC}$, or MC equal to 37.5. The reduction in cost would then only have to be 2.5 , which is 6.25 percent of 40. In this example we assume that all of the firms realize the same efficiencies. In the event that only the merging firms realize the efficiencies, the analysis will necessarily be somewhat different.

${ }^{75}$ The same analysis also applies to cooperative buying groups. See Roger D. Blair \& Jeffrey L. Harrison, Cooperative Buying, Monopsony Power, and Antitrust Policy, 86 Nw. U. L. Rev. 331 (1992)

${ }^{76}$ When two firms merge, the Herfindahl-Hirschman Index (HHI), which is the sum of the squared market shares of the firms in an industry, increases by twice the product of their premerger market shares. For example, if a firm with a 10 percent share merged with a firm holding a 5 percent share, the HHI would rise by $2(10)(5)=100$.
} 
mand for the intermediate good is derived from the consumer demand for the final good. ${ }^{77}$ If the cost of transforming the intermediate good into a final good falls, then the derived demand will shift to the right, i.e., the intermediate good becomes more valuable to the buyers. In this case, transactional efficiencies lead to a shift in the derived demand for the intermediate good in question. The economic effects are illustrated in Figure 2.

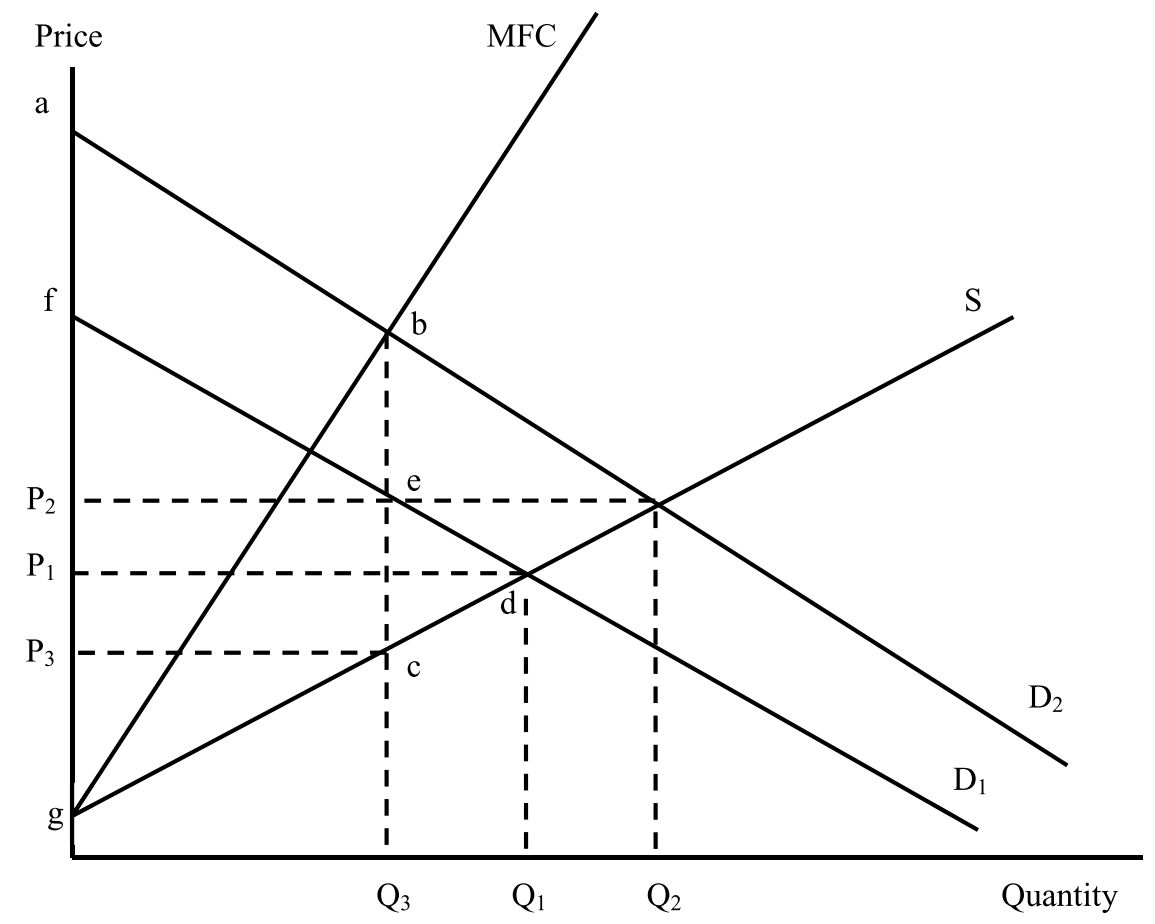

FIGURE 2: EFFICIENCY TRADE-OFFS BY BUYERS

The pre-merger price $\left(\mathrm{P}_{1}\right)$ and quantity $\left(\mathrm{Q}_{1}\right)$ are determined by the equality of derived demand $\left(D_{1}\right)$ and supply $(S)$. The efficiencies resulting from the merger of buyers lead to a shift in the derived demand from $\mathrm{D}_{1}$ to $\mathrm{D}_{2}$. If the merger of formerly competing buyers confers no monopsony power, then the quantity will expand to $\mathrm{Q}_{2}$ due to the increased value of the intermediate good. Due to the positively-sloped supply, price rises from $\mathrm{P}_{1}$ to $\mathrm{P}_{2}$. In this case, everyone is a winner as buyer surplus and producer surplus both increase. ${ }^{78} \mathrm{As}$

\footnotetext{
${ }^{77}$ For a graphical analysis of derived demand, see Roger D. Blair \& David L. Kaserman, Antitrust ECONOMics 321-23 n.65 (2d ed. 2008).

${ }^{78}$ We refer to buyer surplus rather than consumer surplus because the buyers of the intermediate good are firms. The concept is the same.
} 
a result, total welfare rises. Such mergers obviously should be permitted as they pose no competitive threats.

If, however, the efficiency-enhancing merger results in monopsony power, the quantity purchased will be determined by the equality of the marginal factor cost (MFC) and the derived demand $\left(\mathrm{D}_{2}\right){ }^{79}$ In Figure 2, the profit maximizing quantity falls from $Q_{1}$ to $Q_{3}$ and the price also falls from $P_{1}$ to $P_{3}$. As a result, there is a welfare loss due to allocative inefficiency as well as enhanced buyer surplus that flows from the efficiency. ${ }^{80}$ To be sure, there will be an increase in buyer surplus that is simply a transfer from producers. But there is additional buyer surplus that results from the efficiency. It is only the latter that should be compared to the allocative inefficiency in evaluating the impact on total welfare.

If the lawfulness of this merger depends solely on its impact on the competitive suppliers, then the merger would be unlawful due to the reduction in producer surplus from the pre-merger area $\mathrm{P}_{1} \mathrm{dg}$ to the post-merger area $\mathrm{P}_{3} \mathrm{cg}$. On total welfare grounds, however, the allocative inefficiency captured by the triangular area edc must be compared to the reduction in cost captured by the area between the two derived demand curves, i.e., area abef. If the cost savings outweigh the allocative inefficiency, then the merger should be allowed; otherwise, it should not.

In the event that the reduction in transaction costs outweighs the allocative inefficiency, the merger should be permitted. The merger is Kaldor-Hicks efficient because the winners (the buyers) could compensate the losers (the suppliers) and still be better off. But this need not always be the case. When the allocative inefficiency outweighs the cost saving, the merger reduces both producer welfare and total welfare. The merger is inefficient on the KaldorHicks criterion because the winners cannot profitably compensate the losers. Such a merger should be forbidden. Since we cannot presume that the net effect of an efficiency-enhancing merger of rival buyers will inevitably be positive or negative, we need reliable estimates of the prospective cost savings and the prospective allocative inefficiency. This is again a particularly daunting requirement because both estimates are needed before the merger is actually approved.$^{81}$ Mergers that have already been consummated can, of course,

\footnotetext{
${ }^{79}$ For a compact development of the theory of monopsony, see Roger D. Blair \& Christine Piette Durrance, The Economics of Monopsony, in 1 ABA Section of Antitrust Law, Issues in Competition Law and Policy 393 (W. Dale Collins ed., 2008).

${ }^{80} \mathrm{It}$ is possible for the derived demand to shift enough for the post-merger quantity to increase in spite of the monopsony power. In this event, producer surplus would increase even though there would be some allocative inefficiency. This is the second possible outcome of a merger that was described earlier (in which prices rise but not all the way to the competitive level).

${ }^{81}$ This is even more complicated when the merger stops short of monopsony. In that event, the merged firm experiences cost savings while its rivals do not, but all buyers realize price
} 
be challenged after the fact. In that event, proof of the cost saving will be possible - at least in principle_-but estimating the allocative inefficiency will be no easy task.

\section{Merger Law and Efficiencies-Which Standard?}

Williamson's analysis of mergers allows for an exploration of how the U.S. antitrust agencies and courts view merger efficiencies in the law. Cost savings that result from merger-specific productive efficiencies that do more than increase the merging parties' profits are important. Since resources are freed up, consumers benefit from lower prices in other markets. Yet, this is not always clear in the law. ${ }^{82}$ As the previous examples suggest, a merger may generate merger-specific efficiencies that do not result in a lower price but do improve total welfare because of the savings in production costs.

For the most part, the treatment of efficiencies in the 2010 Merger Guidelines remains unchanged from the 1992/1997 version. ${ }^{83}$ Both the 1992/1997 and the 2010 Merger Guidelines have discussed the Williamson trade-off as part of what they term a "sliding scale" approach for efficiencies analysis. The 2010 Merger Guidelines, in particular, make it clear that a consumer welfare standard is employed when analyzing short-term effects. The Guidelines state, "The greater the potential adverse competitive effect of a merger, the greater must be the cognizable efficiencies, and the more they must be passed through to consumers, for the Agencies to conclude that the merger will not have an anticompetitive effect in the relevant market." ${ }^{84}$ The 2010 Merger Guidelines explain the sliding scale's use of consumer welfare as follows: "In adhering to this approach, the Agencies are mindful that the antitrust laws give competition, not internal operational efficiency, primacy in protecting customers." ${ }^{\circ 5}$

decreases and higher profits. The other firms would appear to have an incentive to merge to realize similar cost savings. This could result in further decreases in price and further antitrust enforcement issues. Moreover, if the merger turns out to be unlawful, the remedy may involve "unscrambling the eggs."

82 In the case law, the impact of efficiencies has suggested an exclusive focus on consumer welfare over total welfare. This is true not merely in the merger arena but across antitrust cases. Hovenkamp, Distributive Justice, supra note 13, at 11 ("[I]f the evidence in a particular case indicates that a challenged practice facilitates the exercise of market power, resulting in output that is actually lower and prices that are actually higher, then tribunals uniformly condemn the restraint without regard to offsetting efficiencies. Indeed, I have not been able to find a single appellate decision that made a fact finding that a challenged practice resulted in lower market wide output and higher prices, but that also went on to approve the restraint because proven efficiencies exceeded consumer losses.").

${ }^{83}$ D. Daniel Sokol \& James A. Fishkin, Antitrust Merger Efficiencies in the Shadow of the Law, 64 VAND. L. Rev. EN BANC 45, 55-56 (2011).

${ }^{84}$ U.S. Dep't of Justice \& Fed. Trade Comm'n, Horizontal Merger Guidelines $§ 10$ (2010), available at http://ftc.gov/os/2010/08/100819hmg.pdf.

${ }^{85} \mathrm{Id}$. 
This is not to suggest that the 2010 Merger Guidelines wholly embrace a consumer welfare standard. There is also language in the 2010 Merger Guidelines that suggests the possibility of a total welfare standard..$^{86}$ To date, however, no case has cited to this particular sentence to justify efficiencies.

There are some caveats to analyzing decided merger cases. Litigated cases involving merger efficiency claims are not reflective of all merger matters. ${ }^{87}$ Many litigated cases that include efficiencies discussions are preliminary injunction cases, rather than cases decided by a trial on the merits. ${ }^{88}$ But the litigated merger cases impact what happens in negotiations between the merging parties and the agencies in the shadow of the law. ${ }^{89}$ The cases that have been litigated that include an efficiency discussion have dicta that strongly suggest a consumer welfare standard for merger review..$^{90}$ The courts have adopted the thinking and language of the 1992/1997 Merger Guidelines. This is true of the efficiencies section of the Guidelines. ${ }^{91}$

${ }^{86} \mathrm{Id}$. $\$ 10 \mathrm{n} .15$ ("The Agencies also may consider the effects of cognizable efficiencies with no short-term, direct effect on prices in the relevant market.").

${ }^{87}$ Sokol \& Fishkin, supra note 83, at 47-51; Robert Pitofsky, Panel on Efficiencies/Dynamic Analysis/Integrated Analysis, U.S. Dep't of Justice/Federal Trade Comm'n Merger Enforcement Workshop 82-83 (Feb. 19, 2004), available at http://www.ftc.gov/bc/mergerenforce/040219ftctrans.pdf ("Incidentally, there was a comment that courts almost never say [a merger is] illegal, but because of the efficiencies, I'll make it-I'll call it legal. I believe the reason for that is the agency doesn't bring cases that are barely illegal but with substantial efficiencies. And therefore, the courts haven't had a shot at this, and I'm not sure they're going to get a shot very soon, because the agencies are very sensitive to claims of efficiency.").

${ }^{88}$ Nor do litigated cases address consent decrees, deals that get approved within the first thirty days, or after a second request without a consent order.

${ }^{89}$ Sokol \& Fishkin, supra note 83 , at 45 . This is particularly true as there have not been any litigated cases that are close such that efficiency claims could overcome the agencies' alleged anticompetitive effects. $I d$. at 52 .

${ }^{90}$ FTC v. Arch Coal, Inc., 329 F. Supp. 2d 109, 153 (D.D.C. 2004) ("The existence of such efficiencies, therefore, remains relevant to an assessment of the post-merger market and the potential benefits to consumers from cost reductions and increased competition.”); FTC v. Cardinal Health, Inc., 12 F. Supp. 2d 34, 62 (D.D.C. 1998) ("[T]he FTC does not contest that the mergers will result in large-scale efficiencies, some of which will be passed on to the consumer . ..."); FTC v. Staples, Inc., 970 F. Supp. 1066, 1091 (D.D.C. 1997) ("The Court has no doubt that a portion of any efficiencies achieved through a merger of the defendants would be passed on to customers.”); United States v. Long Island Jewish Med. Ctr., 983 F. Supp. 121, 136-37 (E.D.N.Y. 1997) ('In sum, to sustain an 'efficiencies defense,' the defendants must clearly demonstrate that the proposed merger itself will create a net economic benefit for the health care consumer.").

${ }^{91}$ See William J. Kolasky \& Andrew R. Dick, The Merger Guidelines and the Integration of Efficiencies into Antitrust Review of Horizontal Mergers, 71 AnTitrust L.J. 207, 232 (2003) ("The courts have largely adopted the analytical framework for evaluating efficiency claims that is set out in the Guidelines."); see also Hillary Greene, Guideline Institutionalization: The Role of Merger Guidelines in Antitrust Discourse, 48 WM. \& MARY L. Rev. 771 (2006) (describing the adoption of the merger guidelines by courts); D. Daniel Sokol, Antitrust, Institutions and Merger Control, 17 Geo. Mason L. Rev. 1055, 1106-09 (2010). 
The one case in which efficiencies played a central role was FTC v. H.J. Heinz Co., a three-to-two merger involving baby food. ${ }^{92}$ In that case, the court discussed the need for "extraordinary efficiencies" (although what might constitute "extraordinary efficiencies" is not made clear). However, in doing so, the court did not distinguish which standard might be at play. Indeed, the lower court decision cited by the Heinz court in dicta, University Health, states that "a defendant who seeks to overcome a presumption that a proposed acquisition would substantially lessen competition must demonstrate that the intended acquisition would result in significant economies and that these economies ultimately would benefit competition and, hence, consumers." 93 The problem with this dicta is that what might benefit competition (total welfare) may be at odds in some set of cases with what might benefit consumers (consumer welfare). On this point, the Heinz court and the agencies are silent.

\section{COUNTERVAILING POWER AND ECONOMIC WELFARE ${ }^{94}$}

In this section, we examine the somewhat misunderstood case of bilateral monopoly. Mergers (or agreements) that convert monopoly (or monopsony) to bilateral monopoly are welfare-enhancing. This poses serious problems for antitrust policy. This analysis is somewhat tricky because monopoly (or monopsony) in response to lawful monopsony (or monopoly) leads to welfare gains. The impact on transaction prices is actually irrelevant in this setting, and that may need more careful explanation.

Agreements among ostensibly competing sellers on price and output are usually unlawful per se. Typically, the formation of cartels is intended to emulate monopoly with its attendant welfare losses, which warrants harsh treatment. ${ }^{95}$ The ultimate "agreement" is a merger of the competing sellers. But merging to monopoly would seem to fly in the face of Section 7 of the Clayton Act, which forbids mergers that may substantially lessen competition or tend to create a monopoly in the relevant market. In the absence of the efficiencies considered in the preceding section, this appears to be a sound prophylactic rule as it prevents the deterioration of market structure that would lead to both consumer welfare losses and total welfare losses. But that is not always the case because the buying side of the market may not be competitively structured. When competitive sellers are confronted by a lawful monopsony, merger to monopoly creates a bilateral monopoly, which is a market

\footnotetext{
${ }^{92}$ FTC v. H.J. Heinz Co., 246 F.3d 708 (D.C. Cir. 2001).

${ }^{93}$ FTC v. Univ. Health, Inc., 938 F.2d 1206, 1223 (11th Cir. 1991), cited by Heinz, 246 F.3d at 720 .

${ }^{94}$ See John Kenneth Galbraith, American Capitalism: The Concept of CounterVAILING Power (1952) (providing an early discussion of countervailing power).

${ }^{95}$ D. Daniel Sokol, Cartels, Corporate Compliance and What Practitioners Really Think About Enforcement, 78 AnTitrust L.J. 201 (2012).
} 
with one buyer and one seller. ${ }^{96}$ The same, of course, is true for a cartel that forms in response to monopsony. Bilateral monopoly has superior welfare properties relative to the prior market structure. ${ }^{97}$ In this event, such an agreement or a merger should survive a rule of reason analysis because there is a total welfare improvement. This case, however, demands some careful analysis. ${ }^{98}$

\section{A. Agreements and Mergers Among Sellers}

The economic consequences of an agreement or a merger among former competitors in response to monopsony can be analyzed by referring to Figure 3. We begin with a monopsonist buying from a competitive industry. ${ }^{99}$ The adverse welfare effects of monopsony can be seen in Figure 3.

Under competitive conditions, demand (D) and supply (S) determine a price of $\mathrm{w}_{1}$, and a quantity of $\mathrm{Q}_{1}{ }^{100}$ Buyer surplus ${ }^{101}$ is equal to area $\mathrm{abw}_{1}$, while producer surplus equals area $\mathrm{w}_{1} \mathrm{bc}$. The sum, area $\mathrm{abc}$, is total welfare.

In contrast, suppose there is a single buyer, that is, a monopsonist. The monopsonist can take advantage of the positively sloped supply curve by restricting its purchases and thereby depressing the price that it pays. To maximize its profits, the monopsonist will purchase at the point where the marginal factor cost (MFC) equals demand. ${ }^{102}$ At this reduced quantity $\left(\mathrm{Q}_{2}\right)$, the price

${ }^{96}$ This term does not refer to the case of a monopolist in the output market that is a monopsonist in an input market.

${ }^{97}$ The correct analysis of bilateral monopoly can be traced at least to A.L. Bowley, Bilateral Monopoly, 25 ECON. J. 651 (1928). Most microeconomic textbooks compare the monopoly solution and the monopsony solution and then argue that the bilateral monopoly solution is indeterminate. Specifically, they argue that the price would fall between the monopoly and monopsony level as would the quantity, but they do not state by how much. This is wrong. Blair, Kaserman, and Romano note instead that the quantity is determinate, but that the price is indeterminate. Roger D. Blair, David L. Kaserman \& Richard E. Romano, A Pedagogical Treatment of Bilateral Monopoly, 55 S. Econ. J. 831 (1989).

${ }^{98}$ See Richard Friedman, Antitrust Analysis and Bilateral Monopoly, 1986 Wis. L. Rev. 873 (1986).

${ }^{99}$ The case of a monopolist selling to competitive buyers has precisely the same antitrust significance. The analysis is symmetric.

${ }^{100} \mathrm{We}$ use $\mathrm{P}$ for output prices and $\mathrm{W}$ for input prices.

${ }^{101}$ We are using the term "buyer surplus" because in most monopsony settings the buyers are firms rather than consumers. The concept, however, is the same and it represents the difference between willingness to pay and the price actually paid.

102 The profit function for a firm with monopsony power in the market for one input, say $\mathrm{x}_{1}$, can be written as:

$\pi=P Q\left(x_{1}, x_{2}\right)-w_{1}\left(x_{1}\right) x_{1}-w_{2} x_{2}$, where $\mathrm{P}$ is output price, $\mathrm{Q}\left(\mathrm{x}_{1}, \mathrm{x}_{2}\right)$ is the production function, and $\mathrm{w}_{1}$ and $\mathrm{x}_{1}$ are the price and quantity of $\mathrm{x}_{\mathrm{i}}$. The first-order condition for profit maximization of interest is:

$$
\frac{\partial \pi}{\partial x_{1}}=P \frac{\partial Q}{\partial x_{1}}-w_{1}-x_{1} \frac{d w_{1}}{d x_{1}}=0
$$


on the supply curve is $w_{2}$. The result is a reduction in producer surplus from $\mathrm{w}_{1} \mathrm{bc}$ to $\mathrm{w}_{2} \mathrm{ec}$. Part of this reduction, area $\mathrm{w}_{1} \mathrm{few}_{2}$, is converted into buyer surplus, and part of it is lost. The net effect on total welfare is a loss equal to triangular area dbe. ${ }^{103}$ Thus, the welfare results of monopsony are analogous to those of monopoly. An unlawful monopsonist reduces total welfare as well as producer welfare. The analogous value to the consumer surplus is the reduction in producer surplus created by the buyer's monopsony power. ${ }^{104}$

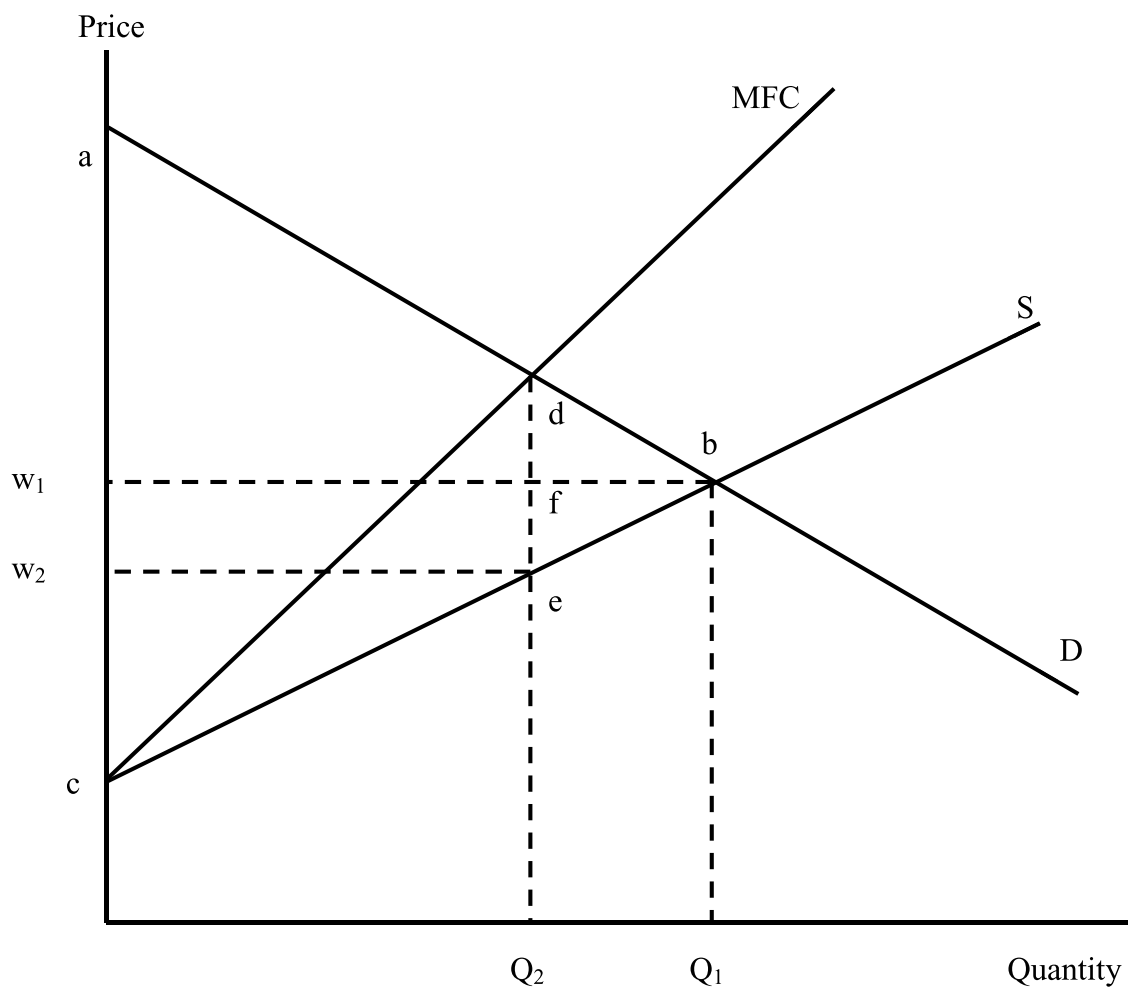

FIGURE 3: COMPETITIVE EFFECTS OF BILATERAL MONOPOLY

The monopsony solution in Figure 3 involves a price of $\mathrm{w}_{2}$ and a quantity of $\mathrm{Q}_{2}$. The sum of producer surplus and buyer surplus is equal to the area

The value of the marginal product, $\mathrm{P} \partial \mathrm{Q} / \partial \mathrm{x}_{1}$, is the demand for $\mathrm{x}_{1}$ while $\mathrm{w}_{1}+\mathrm{x}_{1}\left(\mathrm{dw} / \mathrm{dx}_{1}\right)$ is the marginal factor cost. Since $\mathrm{dw}_{1} / \mathrm{dx}_{1}$ is positive, MFC $>\mathrm{w}_{1}$.

${ }^{103}$ Although it may be somewhat counterintuitive, the lower price paid by the monopsonist does not result in lower output prices. See Blair \& Durrance, supra note 79.

104 The Supreme Court has long understood this parallel. In Mandeville Island Farms v. American Crystal Sugar Co., 334 U.S. 219 (1948), for example, sugar beet farmers complained that the refiners colluded in an effort to depress the prices that they paid for the sugar beets. The Court recognized that the sellers were the victims of the collusive monopsony. 
adec. When the sellers unite through an agreement or a merger, there is monopoly on the selling side and monopsony on the buying side of the market. This is what is known as bilateral monopoly. ${ }^{105}$ The usual marginal analysis fails us here. Neither the monopolist nor the monopsonist can exploit its market power in the usual way. ${ }^{106}$ Normally, a monopolist exploits its power by restricting its output, thereby raising price above the competitive level. The monopsonist curtails its purchases and thereby reduces price below the competitive level. It is clear that these efforts are in conflict. Unilateral efforts to maximize profits will be futile. The solution is cooperation rather than conflict. The buyer and the seller will cooperate to maximize their profits.

It is clear from Figure 3 that the total surplus will be maximized by exchanging $\mathrm{Q}_{1}$ rather than $\mathrm{Q}_{2}$. The total surplus will be equal to the triangular area abc. Since no other volume of output can generate more total surplus, no other quantity makes economic sense. The parties will agree on that quantity and then negotiate over the sharing of the resulting surplus. In a bilateral monopoly, the price is not a rationing device. In other words, it does not lead to increases or decreases in the quantity supplied or purchased. The quantity $\left(Q_{1}\right)$ is determined before the maximized surplus is split. The price is then just a means of sharing the jointly maximized surplus. One price that does just that is $\mathrm{w}_{1}$, but there are many other prices that can be used to split the surplus. In the case of a merger of sellers that were previously being exploited by a monopsonist, one would expect the price to rise. This price increase, however, should be of no competitive concern because the price does not ration; it allocates the surplus between the buyer and seller.

\section{B. Antitrust Policy Analysis}

The cartel agreement or merger to monopoly that creates a bilateral monopoly results in an increase in total surplus and, therefore, would seem to survive a rule of reason test where the goal is total welfare. It is, of course, somewhat disconcerting to endorse monopoly in order to create countervailing power when monopsony is present. But here we began with a lawful monopsony. From the perspective of total welfare, a horizontal agreement or a merger to monopoly is desirable. ${ }^{107}$

105 See, e.g., Appalachian Coals, Inc. v. United States, 288 U.S. 344, 370-71 (1933) (describing a bilateral monopoly involving bituminous coal producers who created an exclusive joint selling agency for what the coal producers agreed would be the best possible price).

106 Technically, the monopolist has no supply function, so the monopsonist cannot move along what is not there. Similarly, the monopsonist has no demand function, so the monopolist cannot move along what is not there. See James M. Henderson \& Richard E. Quandt, Microeconomic Theory 222-26 (3d ed. 1980).

107 This issue is controversial, to say the least. See Tom Campbell, Bilateral Monopoly in Mergers, 74 AnTitRust L.J. 521 (2007) (arguing in favor of such mergers). But see Jonathan B. Baker, Joseph Farrell \& Carl Shapiro, Merger to Monopoly to Serve a Single Buyer: Comment, 
If the goal being pursued is consumer welfare, or in other settings producer welfare, then whether the agreement or the merger to monopoly (or monopsony) passes a rule of reason test does not depend on the consumer price. What matters is the impact on consumer (or producer) surplus. In the case we have analyzed, producers joined together to offset monopsony power, which was presumed to be lawful. Whether the action of the producers is reasonable depends on what happens to consumer surplus. If it rises or remains unchanged, then the producers' behavior is reasonable. If it falls, then that behavior is unreasonable on this standard even though the impact on total welfare is positive. On an a priori basis, the effect on consumer surplus is uncertain because the precise split of the total surplus is indeterminate.

Once the bilateral monopoly structure is in place, the parties rationally agree to the quantity that maximizes total surplus. There are two boundary cases in the subsequent negotiation over price. At one extreme, the price will be so high that the monopolist extracts the entire surplus. At the other extreme, the price is so low that the monopsonist extracts the entire surplus. Any price between these extremes will divide the surplus between the buyer and seller. Any of these prices is a possible solution and, therefore, the effect on buyer surplus or producer surplus is indeterminate.

The change from the monopsony structure to bilateral monopoly is KaldorHicks efficient since the total surplus rises. The sellers join forces through an agreement or a merger to improve producer surplus. This necessarily requires an increase in price, but consumer surplus can rise even at a higher price. Due to the increase in total surplus, both producer surplus and consumer surplus may rise. This, of course, makes a rule of reason inquiry focused on a consumer surplus standard difficult.

\section{Physician Cooperative Bargaining}

As we have seen above, cooperative efforts that stop far short of an actual merger to monopoly may yield total welfare gains if they create a bilateral monopoly. Such gains may result when, for example, health care providers bargain cooperatively with health insurers. ${ }^{108}$ Notwithstanding these potential efficiency gains, cooperation among health care providers to bargain with health insurers over reimbursement rates has been condemned as a violation of Section 1 by the FTC.

75 Antitrust L.J. 637 (2008) (strongly disagreeing with Campbell). For a general discussion of the role of countervailing buyer power in merger analysis, see John B. Kirkwood, Powerful Buyers and Merger Enforcement, 92 B.U. L. REV. (forthcoming 2012).

${ }_{108}$ See Roger D. Blair \& Kristine L. Coffin, Physician Collective Bargaining: State Legislation and the State Action Doctrine, 26 CARDOzo L. Rev. 1731 (2005); Roger D. Blair \& Jill Boylston Herndon, Physician Cooperative Bargaining Ventures: An Economic Analysis, 71 AnTITRust L.J. 989 (2004). 
For example, when hospitals and primary care physicians in southwestern Minnesota joined forces through the Minnesota Rural Health Cooperative (MRHC) to negotiate reimbursement rates with (possibly powerful) health insurers, the FTC filed suit. ${ }^{109}$ The parties entered into a consent order on June 18, 2010, which prohibits the members of the MRHC from continuing their joint efforts. Faced with repeated challenges and recognizing their potential antitrust liability, physicians have appealed to both federal and state legislatures for an antitrust exemption. Federal efforts have failed so far, but there has been some success at the state level. The FTC has advised against such legislation and remains skeptical that monopsony power actually exists. ${ }^{110}$

\section{A Caveat on Countervailing Power}

This analysis cannot be extended too far. For example, one might use this analysis to argue in favor of collusion among sellers to offset collusion among buyers. The theoretical argument still holds, but the obvious antitrust response is to defeat the buyer cartel. The case against merger to monopoly to defeat a buyer cartel is even stronger because the monopoly would be permanent while a buyer cartel may not be permanent. ${ }^{111}$ If a merger were permitted and the buying cartel fell apart, we would then have the monopoly outcome with its Kaldor-Hicks inefficiency and associated welfare losses.

\section{RESTRAINTS WITHOUT ALLOCATIVE INEFFICIENCY}

In this section, we examine restraints that have purely distributional effects. On total welfare grounds, they are unobjectionable, but they are clearly objectionable on consumer welfare grounds. Condemnation of these practices can only be justified if the correct standard is consumer welfare.

Some horizontal restraints are structured in such a way that there is no allocative inefficiency - at least not immediately-but there is a substantial distributive impact on the victims of the restraint. These restraints appear to be welfare-neutral in a Kaldor-Hicks framework since the winners could compensate the losers and not be worse off. At the same time, if the winners actually compensated the losers, they would be no better off. The bottom line is that the total surplus does not change-only the distribution of that surplus changes. If the standard of unreasonableness relies on total welfare, these restraints would pass muster. On the basis of consumer welfare, however, these restraints would fail. In this section, we illustrate this problem with all-or-

\footnotetext{
${ }^{109}$ See Minn. Rural Health Coop., FTC Docket No. 05-0199 (Jan. 8, 2010). The FTC has responded similarly in other cases. See, e.g., N. Tex. Specialty Physicians, FTC Docket No. 0210075 (Sept. 17, 2003); Mem'l Hermann Health Network, FTC Docket No. 031-0001 (Nov. 25, 2003).

${ }^{110}$ Blair \& Harrison, supra note 48, at 211.

${ }^{111} I d$.
} 
none offers, two-part pricing, and bid rigging in single-item English auctions. In each case, the pricing would be permissible if done unilaterally, but would be unlawful per se if it were the product of horizontal collusion.

\section{A. All-or-None OfFers}

In some circumstances, ostensible competitors can collude and impose allor-none offers. ${ }^{112}$ Here we examine the behavior of colluding sellers, but analogous results flow from collusion among buyers. ${ }^{113}$ In either case, there is no allocative inefficiency because the solution involves the competitive output. For a seller cartel, we illustrate this result in Figure 4.

The usual demand curve is represented by $\mathrm{D}$ and the associated marginal revenue is represented by MR. Long-run supply (LRS) and long-run marginal cost (LMC) are assumed to be constant. ${ }^{114}$ The competitive solution results in a price of $P_{1}$ and a quantity of $Q_{1}$. In the cartel solution, price rises to $P_{2}$ and quantity falls to $\mathrm{Q}_{2}$. This behavior reduces, but does not completely eliminate, consumer surplus. It also involves the usual allocative inefficiency, which is measured as the deadweight welfare loss. ${ }^{115}$

If the cartel can make all-or-none offers, the choice available to consumers is altered in a significant way. ${ }^{116}$ Normally, consumers observe the price and can buy as much or as little as they want, which is why consumers buy $\mathrm{Q}_{1}$ when the price is $\mathrm{P}_{1}$ but only $\mathrm{Q}_{2}$ when the price is $\mathrm{P}_{2}$. In an all-or-none offer, the seller offers to sell a specific quantity at a specific price. The buyer either accepts that offer or buys nothing at all. It is in the buyer's interest to accept that offer provided that consumer surplus does not fall below zero.

In Figure 4, the cartel will offer to sell $\mathrm{Q}_{1}$ at a price of $\mathrm{P}_{2}$. The gain in consumer surplus on the first $\mathrm{Q}_{2}$ units is just offset by the loss in consumer surplus by having to buy an additional $\mathrm{Q}_{1}-\mathrm{Q}_{2}$ units at the monopoly price. That is, area $\mathrm{abP}_{2}$ is just equal to area bcd.

The result of this all-or-none offer is a price of $\mathrm{P}_{2}$, which is the usual monopoly price, and the competitive quantity $\mathrm{Q}_{1}$. There is no allocative ineffi-

\footnotetext{
2001).

112 See e.g., Sony Elecs., Inc. v. Soundview Tech., Inc., 157 F. Supp. 180, 184-88 (D. Conn.

${ }^{113}$ See Blair \& HarRison, supra note 48, at 50-53 (analyzing buyer cartels); Jill Boylston Herndon, Health Insurer Monopsony Power: The All-Or-None Case, 21 J. Health Econ. 197 (2002) (analyzing buyer cartels in the health care sector).

${ }^{114}$ Horizontal supply results from constant input prices and access by all firms to the same production technology. Industry output then changes with the expansion or contraction in the number of firms in the industry.

115 This welfare loss is captured by the triangle bde. See Part III (Fig. 3) above.

116 See Milton Friedman, Price Theory 15-16 (1976) (analyzing the all-or-none demand curve).
} 
ciency and, therefore, no total welfare loss. The effect is purely distributive. ${ }^{117}$ With competition, consumer surplus is equal to area $\operatorname{adP}_{1}$, but with cartelization that area becomes profit for the colluding sellers.

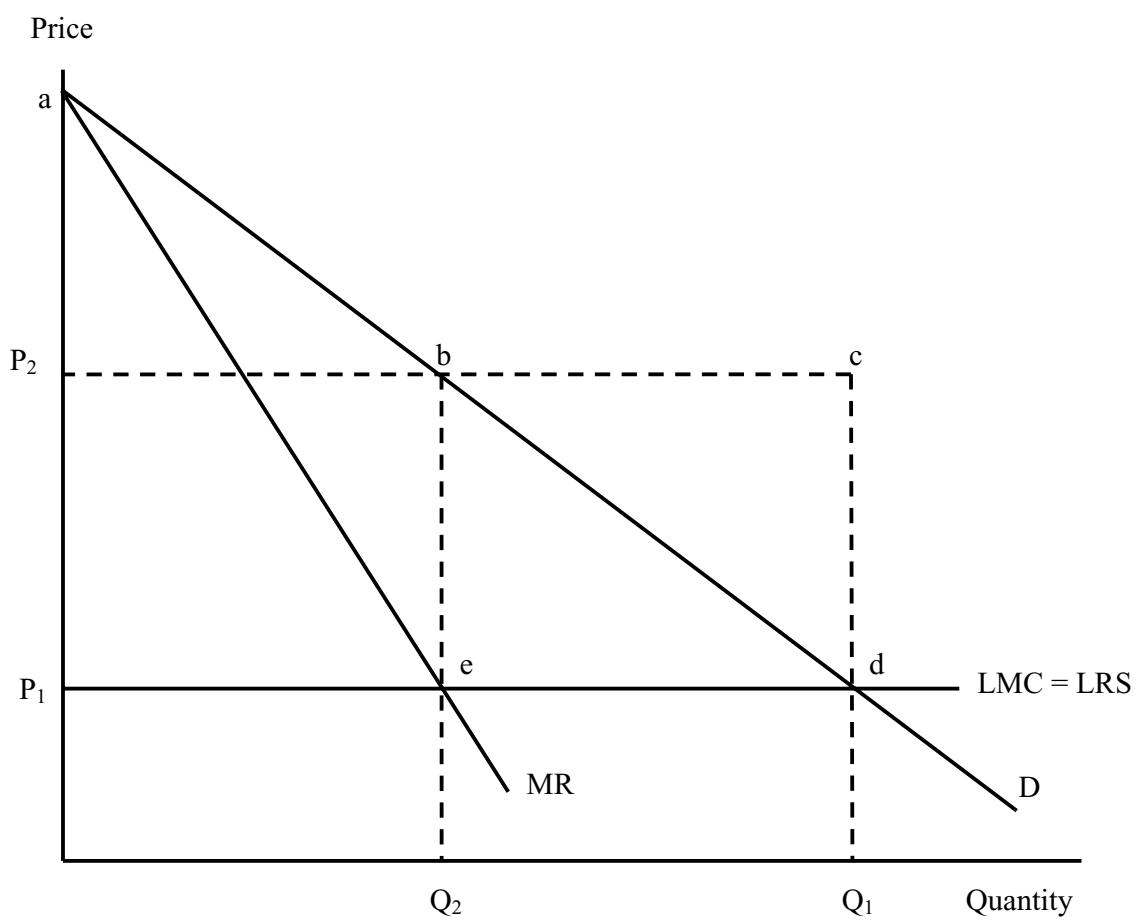

FIGURE 4: ALL-OR-NONE OFFERS

\section{B. Two-Part Pricing ${ }^{118}$}

Collusion among sellers can also lead to two-part pricing. ${ }^{119}$ In this case, the buyer pays a lump-sum access fee and then can buy as much or as little as he or she wants at a price (i.e., a user fee) equal to marginal cost, which would be

117 This is strictly true only when the cartel makes no mistake on its price and quantity offer. If the offer leads to a quantity below $\mathrm{Q}_{1}$, there will be some allocative inefficiency. Over time, this should be corrected because the cartel can earn more profits by getting to the competitive quantity.

118 There are many examples of two-part pricing. Tennis clubs often have annual dues as well as a charge for court time. Netflix has monthly fees and user fees equal to a marginal cost of zero.

119 See Walter Y. Oi, A Disneyland Dilemma: Two-Part Tariffs for a Mickey Mouse Monopoly, 85 Q.J. ECON. 77 (1971) (introducing the model). In the antitrust case law context, this is a theory at play in FTC v. H.J. Heinz Co., 246 F.3d 708 (D.C. Cir. 2001). See Gregory J. Werden, Monopsony and the Sherman Act: Consumer Welfare in a New Light, 74 ANTITRUST L.J. 707, 731 (2007) (analyzing the two-part pricing theory in Heinz). 
the competitive price. ${ }^{120}$ Again, there is no apparent allocative inefficiency. This pricing strategy is illustrated in Figure 5.

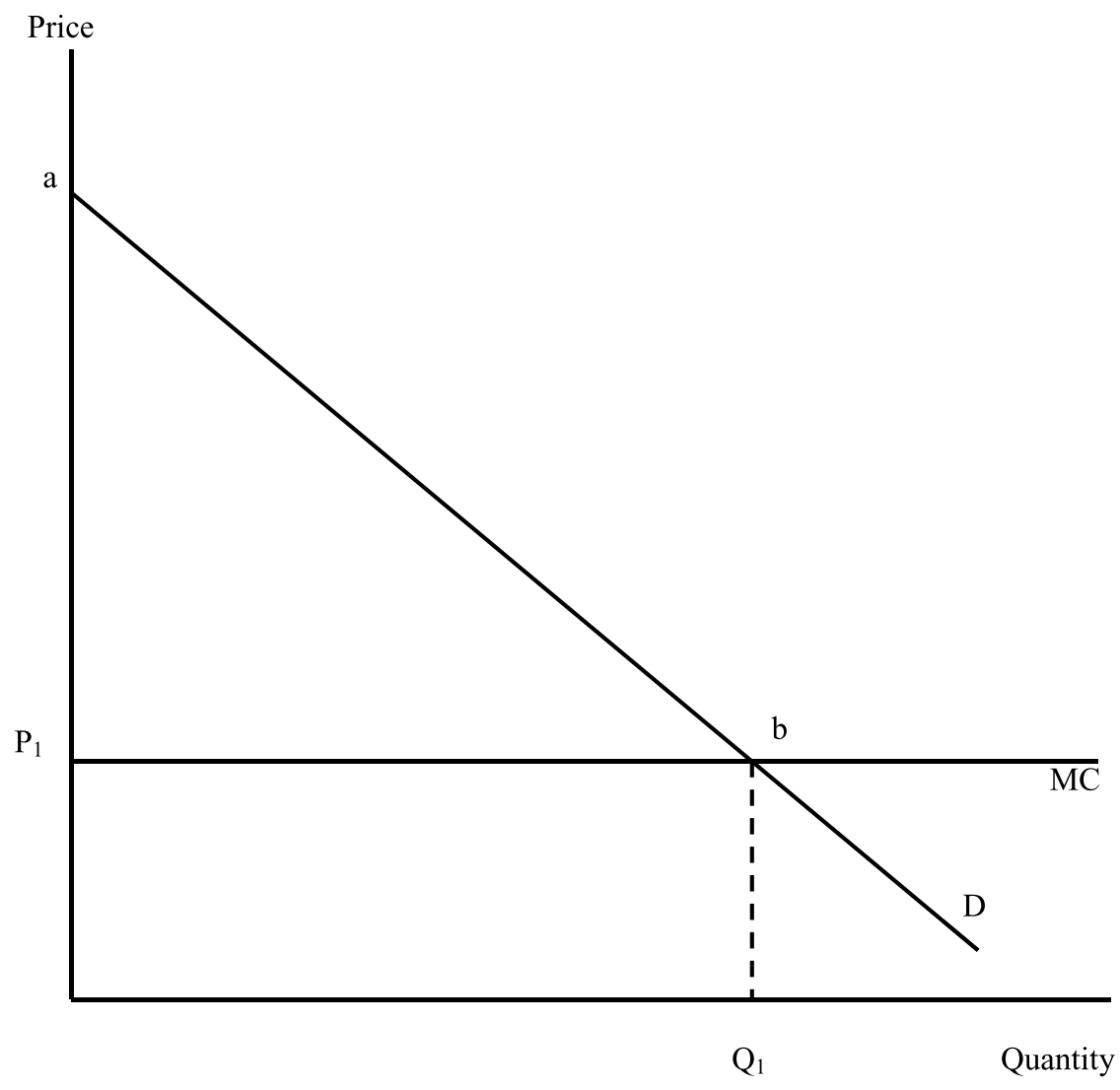

FIGURE 5: TWO-PART PRICING

Demand of a consumer is given by $\mathrm{D}$ and the marginal cost of producing the good is represented by MC. The competitive price would be equal to $\mathrm{P}_{1}$, which is equal to marginal cost. The quantity consumed is $\mathrm{Q}_{1}$. The consumer surplus is equal to the triangular area $\mathrm{abP}_{1}$ and producer surplus is equal to zero.

If collusion permits two-part pricing, the sellers will be able to charge an access fee equal to the consumer surplus $\left(a r e a a b_{1}\right.$ ) and guarantee a user fee equal to marginal cost. Thus, output remains at $\mathrm{Q}_{1}$ and the user fee is $\mathrm{P}_{1}$. The

${ }^{120}$ This simple solution assumes that all consumers have identical demands. If they do not, two-part pricing becomes much more complicated. The simple case is used here to illustrate rule of reason problems. 
entire consumer surplus has been extracted through the access fee. There is no allocative inefficiency since the competitive quantity is consumed. The impact of the collusion is purely distributional since consumer surplus is now zero.

\section{Collusion in Bidding}

In an English auction, an item is offered for sale and potential buyers offer ascending bids for the item. The final price is determined by the highest bidder. ${ }^{121}$ Collusion among buyers at an English auction can lead to a redistribution of surplus without any apparent allocative inefficiency. ${ }^{122}$ Suppose that a single item is being sold at auction. If all bidders have common values, competition among them will drive the price up to that value in an ascending-price English auction. If the seller's reserve price is below that common value, the item will be sold and the seller will enjoy surplus equal to the difference between the competitive price and the reserve price, which is the lowest price that the seller accepts. Anything above the reserve price confers surplus on the seller.

Collusion among bidders will lead to a price at or just barely above the seller's reserve price. The seller will still sell the item, but all (or nearly all) of the surplus goes to the colluding buyers who share it in some fashion. In this case, there is no allocative inefficiency, but there are dramatic distributive consequences. ${ }^{123}$

\section{Antitrust Policy Dilemma}

The collusive practices we have examined in this section are per se violations of Section 1 of the Sherman Act. None of them is ancillary to a legiti-

\footnotetext{
121 There is an enormous theoretical literature on auctions. See, e.g., Louis Phlips, The EcoNOMics OF IMPERFECT InFORMATION 89-121 (1988); Paul Klemperer, Auction Theory: A Guide to the Literature, 13 J. ECON. Survs. 227 (1999).

122 Robert C. Marshall \& Leslie M. Marx, Inefficiency of Collusion at English Auctions, ConTrib. TheOretical Econ. (2004); see also Blair \& Harrison, supra note 48, at 50-53 (examining bidder cartels); Masaki Aoyagi, Bid Rotation and Collusion in Repeated Auctions, $112 \mathrm{~J}$. ECON. THEORY 79 (2003) (examining buyer collusion in the auction context); Robert C. Marshall \& Michael J. Meurer, Bidder Collusion and Antitrust Law: Refining the Analysis of Price Fixing to Account for the Special Features of Auction Markets, 72 AnTitrust L.J. 83 (2004); R. Preston McAfee \& John McMillan, Bidding Rings, 82 Am. Econ. Rev. 579 (1992); Marc S. Robinson, Collusion and the Choice of Auction, 16 RAND J. ECON. 141, 143 (1985). For empirical papers on auction collusion, see, e.g., Peter Cramton \& Jesse A. Schwartz, Collusive Bidding: Lessons from the FCC Spectrum Auctions, 17 J. REG. Econ. 229 (2000); and Rieko Ishii, Favour Exchange in Collusion: Empirical Study of Repeated Procurement Auctions in Japan, 27 INT'L J. INDUS. ORG. 137 (2009).

123 The case law regarding collusion among bidders traces back to United States v. Addyston Pipe \& Steel Co., 85 F. 271 (6th Cir. 1898), aff'd as modified, 175 U.S. 211 (1899). In some cases, there are social benefits to collusion among bidders in auctions. Marshall \& Meurer, supra note 122 , at $99-100$.
} 
mate business venture, which can provide antitrust shelter in some cases. ${ }^{124}$ Instead, each can be characterized as a "naked" restraint of trade. These practices are presumed to be unreasonable and, therefore, unlawful. But each practice involves no allocative inefficiency and, therefore, the practices are not inefficient based on the Kaldor-Hicks criterion. On total welfare grounds, there appears to be nothing to condemn. In fact, the conspirators could argue with some justification that they have not restrained trade. After all, the competitive quantity is transacted in each instance and, therefore, there is no total welfare loss.

From the perspective of consumer welfare, these practices are easy to condemn. Collusion that permits all-or-none offers or two-part pricing leaves consumers with no consumer surplus and clearly makes them worse off. When the buyers collude to make all-or-none offers or to rig bids at auctions, all producer surplus is removed. While there have been a number of courts that have treated buyer side collusion differently because the harm does not reach consumers, who receive lower prices, ${ }^{125}$ this treatment in the case law is not uniform. When examining collusion among buyers, it is the consumers that are colluding, so the court must examine the welfare of the sellers. ${ }^{126}$

In the cases considered above, a total welfare standard does not provide a sufficient foundation for condemning these practices under a rule of reason analysis. In these cases, unreasonableness and, therefore, unlawfulness must be based on considerations of the distributive consequences of the restraints.

The case law in the United States has been silent on the appropriate welfare standard in the context of mergers involving significant efficiencies, but also corresponding increases in price. The welfare standard applied in Canada lies somewhere between a consumer and a total welfare standard. ${ }^{127}$ In Superior Propane, the Canadian Competition Tribunal undertook an analysis that weighed both producer surplus and consumer surplus in a merger that resulted

${ }^{124}$ See Gregory J. Werden, The Ancillary Restraints Doctrine After Dagher, 8 Sedona Conf. J. 17 (2007) (examining the ancillary restraints doctrine).

125 See Hillary Greene, Non-Per Se Treatment of Buyer Price-Fixing in Intellectual Property Settings, 2011 Duke L. \& Tech. Rev. 4, 13 (2011).

${ }^{126}$ From Mandeville Island Farms v. American Crystal Sugar Co., a monopsony case involving sugar beet farmers, we may infer that such collusive monopsony behavior would be condemned under a total welfare standard. 334 U.S. 219, 236 (1948) ("The [Sherman Act] does not confine its protection to consumers, or to purchasers, or to competitors, or to sellers. Nor does it immunize the outlawed acts because they are done by any of these.").

127 Comm'r of Competition v. Superior Propane Inc., [2000] C.C.T.D. No. 15, 7 C.P.R. (4th) 385 (Can. Comp. Trib.) (original decision); [2001] 3 F.C. 185 (Fed. Ct. App.) (first Court of Appeal decision), available at http://reports.fja.gc.ca/fc/2001/pub/v3/2001fc28500.html; [2002] C.C.T.D. No. 10, 18 C.P.R. (4th) 417 (Can. Comp. Trib.) (redetermination); [2003] 3 F.C. 529 (Fed. Ct. App.) (second Court of Appeal decision), available at http://reports.fja.gc.ca/fc/2003/ $\mathrm{pub} / \mathrm{v} 3 / 2003 \mathrm{fc} 31974 . \mathrm{html}$. 
in an increase in price along with merger-based savings that resulted from redundancies in management, back office, and staff. ${ }^{128}$

The way to undertake merger analysis that would incorporate a total welfare approach in the United States would be to ex ante estimate the price increase and demand function (the difference in prices and quantities, controlling for other things that cause changes). Companies relying upon a total welfare analysis would need to show specific cost savings that are real and that cannot be realized in the absence of the merger. In this situation there are winners and losers. Under the Kaldor-Hicks criterion, if the winners (the producers) can compensate the losers (the consumers), then the merger is welfare enhancing and should be approved. ${ }^{129}$

While it might be possible for a party to use such a total welfare analysis utilizing the language of Section 10 of the 2010 Merger Guidelines, in a litigated case we think that case law will be slow to develop in this area. Few mergers get litigated on the merits, due to issues, such as short financing windows, the uncertainty that mergers create for employees of the target firm, the benefits of settlement with the agencies via a consent decree, the risk appetite of the acquirer, and the fact that many acquirers are concerned only about their specific deal and not about creating good case law. As a result, to the extent that agencies push to embrace total welfare explicitly, we believe that this may occur by virtue of the decisions the antitrust agency makes regarding whether or not to allow a merger.

\section{CONCLUSION}

Under the antitrust laws, reasonableness is what separates lawful from unlawful restraints or business conduct. If a business practice is reasonable, it is lawful; if it is unreasonable, it is unlawful. Obviously, a crucial first step in evaluating the reasonableness of a business practice is identifying a standard of reasonableness. Since the Sherman Act's text offers no guidance, we naturally turn to the Supreme Court for instruction. As we found in Part II, however, the standard of reasonableness adopted by the Supreme Court is ambiguous. Based on some recent opinions, one might conclude that the impact on consumer welfare will dictate the result. But others might just as easily conclude that total welfare is the guide. From an economic perspective, we advocate total welfare as the standard. It is essential for the Supreme Court to

\footnotetext{
${ }^{128}$ See Thomas W. Ross \& Ralph A. Winter, The Efficiency Defense in Merger Law: Economic Foundations and Recent Canadian Developments, 72 ANTITRust L.J. 471, 487-94 (2005) (exploring the implications of this case and noting that the analysis undertaken was problematic in many respects).

${ }^{129}$ Under total welfare, the producers could compensate the consumers because with significant enough cost savings, producers and consumers will still be better off even if Kaldor-Hicks does not require it.
} 
clarify its standard for analysis if we are going to have logically consistent and economically coherent outcomes.

In many substantive areas of antitrust, both standards yield the same outcome, but there are complications in other areas. This article spells out some of these complications and inconsistencies. A real policy dilemma arises in analyzing cases that have severe distributive effects but involve no allocative inefficiency. The economic analysis of these more complicated issues illustrates the difficulty that is caused by the absence of clear guidance from the Supreme Court. 